DIW BERLIN

Discussion

Papers
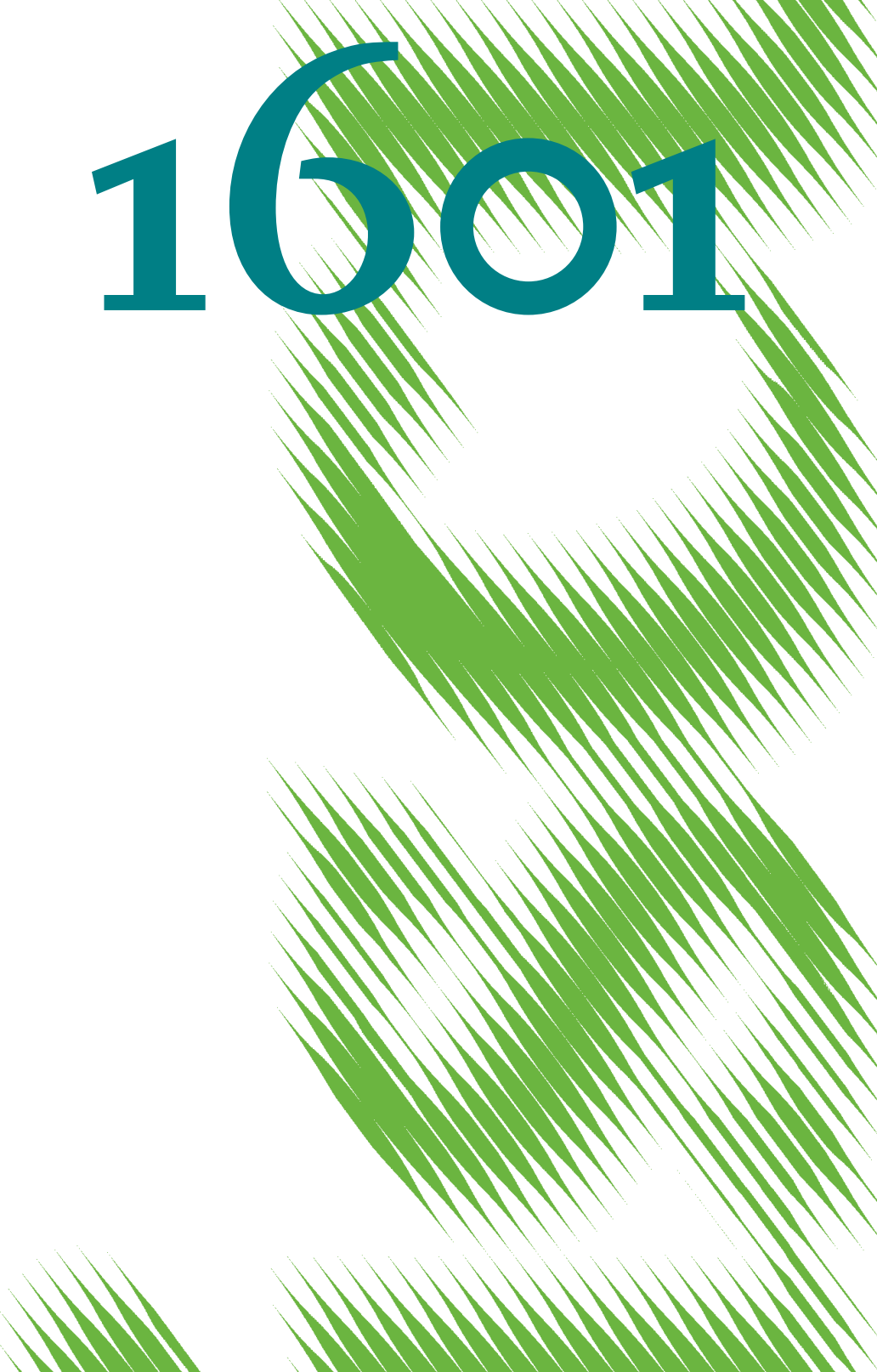

The Valley of Death, the Technology Pork Barrel, and Public Support for Large Demonstration Projects 
Opinions expressed in this paper are those of the author(s) and do not necessarily reflect views of the institute.

IMPRESSUM

(C) DIW Berlin, 2016

DIW Berlin

German Institute for Economic Research

Mohrenstr. 58

10117 Berlin

Tel. +49 (30) $89789-0$

Fax +49 (30) $89789-200$

http://www.diw.de

ISSN electronic edition 1619-4535

Papers can be downloaded free of charge from the DIW Berlin website:

http://www.diw.de/discussionpapers

Discussion Papers of DIW Berlin are indexed in RePEc and SSRN:

http://ideas.repec.org/s/diw/diwwpp.html

http://www.ssrn.com/link/DIW-Berlin-German-Inst-Econ-Res.html 


\title{
The Valley of Death, the Technology Pork Barrel, and Public Support for Large Demonstration Projects
}

\author{
Gregory F. Nemet ${ }^{1}$, Martina Kraus ${ }^{2}$, Vera Zipperer ${ }^{2}$
}

\begin{abstract}
Moving non-incremental innovations from the pilot scale to full commercial scale raises questions about the need and implementation of public support. Heuristics from the literature put policy makers in a dilemma between addressing a market failure and acknowledging a government failure: incentives for private investments in large scale demonstrations are weak (the valley of death) but the track record of governance in large demonstration projects is poor (the technology pork barrel). We reassess these arguments in the literature, particularly as to how they apply to supporting demonstration projects for decarbonizing industry. Conditions for the valley of death exist with: low appropriability, large chunky investments, unproven reliability, and uncertain future markets. We build a data set of 511 demonstration projects in nine technology areas and code characteristics for each project, including timing, motivations, and scale. We argue that the literature and the results from the case studies have five main implications for policy makers in making decisions about demonstration support. Policy makers should consider: 1) prioritizing learning, 2) iterative upscaling, 3) private sector engagement, 4) broad knowledge dissemination, and 5) making demand pull robust.
\end{abstract}

Keywords: demonstrations; technology push; demand pull JEL-Classifications: Q55, O31, O38

\footnotetext{
${ }^{1}$ University of Wisconsin, Madison

${ }^{2}$ DIW Berlin
} 


\section{Introduction}

A prominent claim in innovation literature, and in practice, is that a technology 'valley of death' exists, from which promising technologies fail to emerge due to weak incentives for investment, e.g. due to technical risk, uncertain markets, and the need for large chunky investments. Market failures and innovation system failures lead to underinvestment at this intermediate stage of innovation. While governments might address this problem, a second metaphor holds that a 'technology pork barrel' also exists, in which technology support will inevitably fail due to politicians diverting program goals to trade favors and improve reelection prospects. A related notion holds that even beyond these problems with representative democracy, poor access to information implies that 'governments should not pick winners.' The strong version of these latter arguments, predominant in some countries today, is that even if market and system failures set up a technology valley of death, it is not worth addressing because government failures are so inherent in democracies that they will undermine efforts make technologies commercially viable.

That the extent of government failures may exceed market failures has important implications for technologies facing real valley of death problems; they may simply never become widely adopted. This outcome is particularly relevant for technologies needed to address climate change. For example, achieving the ambitious climate change mitigation targets that 196 countries agreed upon in Paris in December 2015 will require near complete decarbonization of developed countries' economies during this century (Rogelj et al., 2015). This transformation will necessarily involve not only sectors such as electricity and transportation, which are already decarbonizing, but also substantial emission reductions in industrial sectors such as steel and cement in which the core production process produces emissions (Woertler et al., 2013; Ahman et al., 2016; Denis-Ryan 
et al., 2016). While some opportunities remain for picking low hanging fruit, such as emission reductions through energy efficiency improvements, they are not sufficient to achieve the envisaged climate goals (OECD, 2015; Arens and Meister, 2016). Adoption of radical low-carbon innovations in the production process, combined with electrification (IEA, 2014), is crucial to decarbonizing the materials sector (Neuhoff et al., 2015). And because industrial facilities are large to reap scale economies, industrial low-carbon technology needs similar scale to fit into the broader technological system. Large-scale radical innovations with payoffs that depend on uncertain future policies seem especially prone to the valley of death problem. To help improve the prospects of meeting ambitious goals, governments around the world are considering substantial increases in their support for innovation, including demonstration projects. One example is the Mission Innovation initiative, in which 21 governments have committed to double their energy R\&D investment over the next five years (Karlsson, 2016; Sivaram and Norris, 2016). Further the European Commission has proposed a New Entrants' Reserve (NER) 400 program, which would use the revenue from auctioning 400 million emissions permits to fund projects in the 2020s focused on decarbonizing industry (Borghesi et al., 2016). How this support will be structured, allocated, and coordinated are crucial open questions - ones that need more sophisticated guidance than following heuristics such as removing 'barriers' and avoiding 'picking.' Just letting 'markets decide' ignores the reality of substantial market and system failures, while simply beefing up government funding does not adequately address the perceived poor track record of previous government programs. Further, the potential for high-profile failures heightens the stakes involved in that they may create lasting legacies that affect the political feasibility of future efforts.

We thus address the broad question: how can public support for technology 
demonstration projects be structured to be most effective? Our approach is to reexamine the arguments that lead to the notion of the valley of death and the technology pork barrel. We do this in two ways. First, starting with a simple model of government support for innovation based on technology push and demand pull, we review the literature to more precisely understand the conditions that can produce a technology valley of death. Similarly we revisit the arguments, and claims supporting them, that lead to the technology pork barrel view. Second, we build on this reassessment by characterizing important aspects of a large sample past demonstration projects. We develop a data set of 511 demonstration projects, which we code in several ways, including: timing, motivations, contributions, scale-up, performance, and markets. Our primary motivation is to contribute to a (hopefully) growing set of studies about technologies that face the challenges of this awkward intermediate stage, between technology push and demand pull. We hope to help structure thinking, beyond heuristics, about the policy decisions at stake because the policy outcomes have broad ramifications beyond the sums involved, even if those are substantial (Iyer et al., 2015).

Specifically, in this paper we review the state of the literature on technology push, demand pull, the valley of death, and the technology pork barrel. We summarize our approach to addressing our key research questions - this involves assembling a new data set of previous large scale demonstration projects. We develop a response to our research questions with descriptive results on 511 demonstration projects in 9 technology areas. We conclude with a discussion of the implications for policy making. 


\section{Literature, theory, and hypotheses}

Informing decisions about public investments in demonstration projects starts with understanding insights from previous research about government involvement in this particularly challenging stage of the innovation process.

\subsection{Technology Push and Demand Pull}

While more sophisticated theories have emerged, it is difficult to completely discard the nearly century-old notion of the process of innovation as progress along a sequence of stages from scientific research to applied research to commercialization, and diffusion - with various names and fineness in distinctions to describe the stages (Schumpeter, 1947; Usher, 1954). Crucial to moving this model from aged caricature to useful depiction of reality are the feedbacks involved in this sequence. Knowledge created in the process is used to inform thinking and decisions in previous stages. For example, experience in production can identify bottlenecks that require new designs to address; consumer use of new technologies can inform how they can be improved. Once feedbacks of knowledge are included in the previously linear process it takes on the attributes of a system — with complexity, emergent properties, increasing returns, and stochastic outcomes as defining features.

The literature on "technology push" and "demand pull" implies that governments can interact with this system in two ways. In the most succinct terms: technology push policies reduce the costs of innovation for private sector actors while demand pull policies increase the payoffs to private sector actors for successful innovations (Nemet, 2009). In the technology push approach, the government's goal is to increase the availability of new knowledge while in demand pull the goal is to increase the size of markets for commercialized knowledge. Examples of technology push policies include: public R\&D funding, 
R\&D tax credits, subsidizing education, and supporting knowledge networks. Examples of demand pull include: intellectual property rights, pricing externalities, subsidizing demand, government procurement, and technology standards. The innovation literature involves a lengthy debate about this dichotomy including both descriptively about which has been the dominant driver of innovation (Schmookler, 1962; Mowery and Rosenberg, 1979; Godin and Lane, 2013) and normatively about whether governments should focus on creating knowledge or creating markets (Bush, 1945; Veugelers, 2012; Peters et al., 2012). A general consensus has emerged including that: 1) both are necessary and neither is sufficient; given substantial variation among technologies, 2) technology push is important in early stages and demand pull in later stages, 3) incremental innovations depend on demand pull while radical innovations require technology push, and 4) successful innovations tend to be those that "couple" a technical opportunity with a market opportunity (Freeman, 1974; Pavitt, 1984; Arthur, 2007; Di Stefano et al., 2012).

This framework provides a meso-level model of public-private interactionsa simplification relative to the innovation systems perspective in which governments need to address system failures (Carlsson and Stankiewicz, 1991; Bergek et al., 2008), but involving more detail than an economic efficiency perspective in which governments exclusively focus on correcting market failures (Jaffe et al., 2005). In justifying government interventions one could look for systems failures such as inadequately performing functions by entrepreneurs and 'search' directions, or market failures such as: knowledge spillovers, asymmetric information, and risk aversion (Bleda and del Rio, 2013).

This framework is particularly useful for assessing demonstration projects as it illustrates what makes support for them challenging. First, demonstration projects fit awkwardly into this framework as they lie between the research oriented areas associated with technology push and market oriented stages of 
demand pull. Second, in the context of low-carbon technologies, demand pull may be weak due to low credibility that policymakers will create future markets making the resulting incentives fragile.

\subsection{Demonstration projects}

Demonstration projects sit at an awkward stage, in the middle of the innovation process; they are well beyond research but not yet commercial products (Kingsley et al., 1996; Mowery, 1998; Spath and Rohracher, 2010; Hendry and Harborne, 2011). As such, it's not even clear whether government funding for demonstrations involves reducing innovation costs or increasing commercial payoffs. To small suppliers of innovation, a billion dollar demonstration project is the payoff; to large ones it is part of the cost of bringing an innovation to the market. Ultimately, if one were to choose, the latter description seems more representative.

In an excellent review of what they term "pilot and demonstration" projects, Frishammar et al. (2015) make clear that this term has been used in several different ways and thus suggest the rather general definition:

"a tool used to progress knowledge so that an effective organization, design, and management of commercial facilities can be achieved at a lower risk for the stakeholders involved."

This definition reveals that demonstrations often involve multiple objectives. Most fundamentally, their goals can diverge between demonstrations 1) as exemplars, proving reliability and performance and 2) as experiments from which to learn. Demonstrations provide opportunities for collaboration, for example among component suppliers, universities, partner firms, and in some cases customers, so that process and interactions can be standardized and improved. These interactions make clear that the challenges involved are not purely techni- 
cal, encompassing alignment of institutions, rules, standards, codes, and public attitudes. They are also about creating knowledge about technical possibilities, not just creating those possibilities (Weyant, 2011). All of these functions are supportive of a recurring challenge in innovation, scaling up unit size (Wilson, 2012). The scale-up might be needed to achieve some minimum efficient scale, or to fit into a larger technological system.

\subsection{Valley of death: 'between' and fragile}

The notion of the technology valley of death is that technologies at the demonstration stage face particular challenges that lead to under-investment and ultimately to premature deaths of otherwise promising innovations (Murphy and Edwards, 2003; Watson, 2008; Weyant, 2011). Figure 1 portrays the valley of death by showing the shift in funding over the course of the innovation lifecycle, from the public to private, is in part due to declining social returns and increasing private ones. At any stage at which social returns exceed private ones, there will be underinvestment unless the public sector plays a role. For example, at early stages the widespread availability of new knowledge as scientific research makes social value high and easy to access for all. At late stages, there are diminishing returns to adoption and firms are able to protect what value remains via brands, patenting, and optimized proprietary production processes.

Why don't firms pay for their own demonstrations? At either end of the innovation sequence, the optimal roles of the public sector and firms are clear: basic research requires public funding; adoption of commercial technologies are best funded by the private sector, including consumers. However, in between, at the demonstration stage, a troublesome combination of factors is typically involved: the potential for knowledge about outcomes to be highly beneficial to companies other than those making an investment; a substantial increase in the scale of investment required; unproven technical reliability; and uncertain 


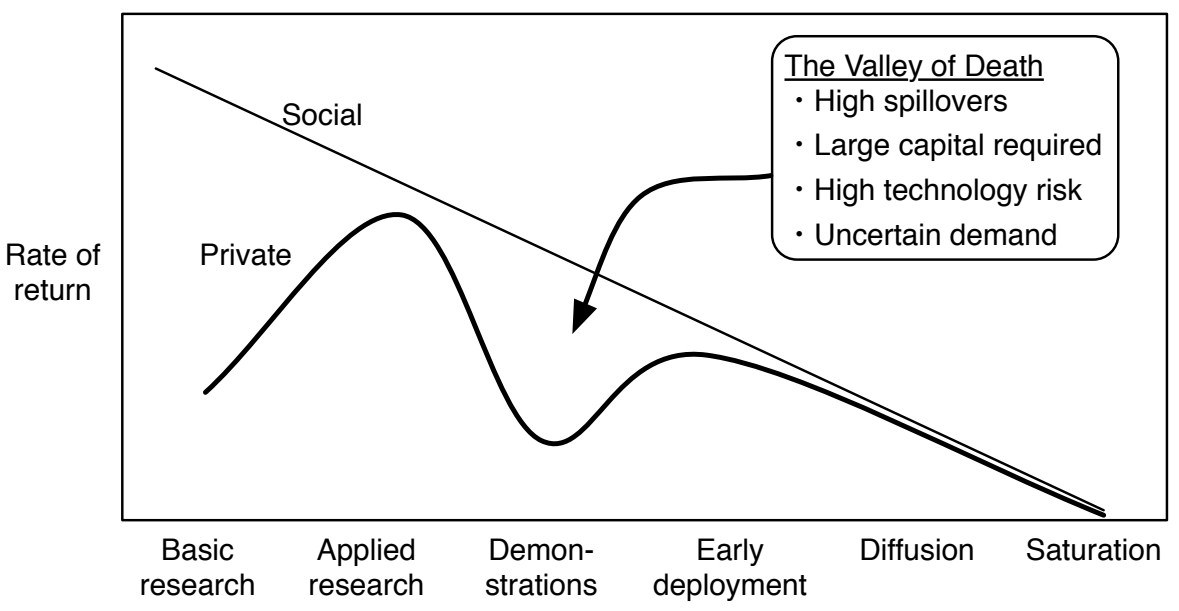

Figure 1: Innovation stages and the technology valley of death.

market receptiveness. Because knowledge about performance may have high value, but may also be non-excludable, social returns to investment at this stage may far exceed private returns. A lack of investment by both the public and private sector has been a frequent result. We describe these four reasons in more detail.

Appropriability Low appropriability is the most widely accepted explanation for why firms will be unwilling to fully fund their own demonstration projects (Teece, 1986; Cohen et al., 2002; Hall et al., 2009). Appropriability is low when knowledge created as a result of a firm's investment 'spills over' to other firms. The most tangible example of spillovers is when firms reverse engineer the products of others; they benefit by being able to imitate a novel design without investing in the expensive and risky process of developing it. Spillovers may also take less tangible forms. For example, employees who accumulate tacit knowledge in developing technology, take that knowledge with them when they move to a new firm. Even more indirectly, firms can observe the behavior of other firms; for example in the case of a large demonstration project like a large industrial facility, a rival might be able to determine how often the facility 
operates, and whether the firm builds more of the same design. In all of these example, firms have an incentive to free-ride on the innovation investments of others. The result in aggregate is under-investment in technology development.

Scale The scale required for innovations to become profitable depends on the production process, the sector, whether the innovation involves a process or product, among other factors. Proving reliability at scale is a challenge, particularly for radical innovations which might depend on large demonstration projects for subsequent commercialization (Wilson, 2012; Funk, 2013). For example, upscaling typically identifies new problems that are not apparent at smaller scales (Sahal, 1985). The capital required for a single demonstration project can be in the 100s of millions of dollars, or even billions. It may even be the case that several demonstration plants will need to be built to sufficiently learn or prove to de-risk the technology and move to commercial production. The required investment may rival the value of the firms themselves making them a potentially unacceptable risk. The under-investment problem due to spillovers is exacerbated if the scales required are large relative to the size of the firms involved.

Radicalness Incentives for private investment in demonstration projects also hinge on the novelty of the innovations. Incremental improvements to existing technologies are more likely to attract financial investment than radical innovations. Radical innovations likely involve more uncertainty over whether they will prove feasible, economical, and reliable (Verhoeven et al., 2016). We also know that radical innovations have bigger knowledge spillovers than incremental ones, as the latter can often be protected by patents or embedded in unobservable production processes (Hurmelinna-Laukkanen et al., 2008). 
Fragile demand pull Incentives to invest in demonstrations may also be weak because expectations about the payoffs are uncertain. This issue is especially problematic for innovations that depend highly on government actions for their payoffs, for example environmental technologies. If future policies are uncertain, investment can be reduced (Kalkuhl et al., 2016; Nemet et al., in review). It is quite clear that weak credibility about government commitments to future policies has been a problem in climate policy (Koch et al., 2015). Where payoffs depend on policies, and especially if lags between investment and payoffs are long, weak policy credibility can make demand pull 'fragile' and thus weaken incentives for demonstration investments.

As the above discussion suggests, the interactions among these factors may be especially problematic. Scale and radicalness may simply exacerbate appropriability problems. Large firms may be able to absorb the risk of investing in billion dollar demonstration programs, but if knowledge spillovers exist, the scale of investment may be too much to overcome. Fragile demand pull may be more of government failure than a market failure. This stage of the technology innovation process is particularly amenable to cost sharing between governments, private firms, and industrial consortia. Investment by the public sector is made difficult however by the need to concentrate substantial funds in a small number of projects. This concentration has made investments at the demonstration stage vulnerable to shifting political support and, conversely, prone to regulatory capture that may excessively prolong programs and funding.

\subsection{Government failures and the technology pork barrel}

As a result, government support of demonstrations involves not only market failure problems but potentially also government failures. The basic argument is that government failures exist that lead to suboptimal implementation of policies to address innovation-related market failures. Several specific mechanisms can 
result in government failure (Weimer and Vining, 2015). Concentrated interest groups in a technology have strong incentives to lobby and thus policy decisions are made with excess weight placed on the costs and benefits of those groups . Because they face elections, representatives have strong incentives to secure and maintain government technology investments in their own districts. This particular mechanism has earned colorful metaphors such as 'log-rolling' and 'pork barrel' politics, to which we return below. Elections may lead representatives to be especially focused on securing funding in the near term, possibly without regard to broader and long term impacts. Problems in bureaucratic supply may also exist. In part because governments do not face competitors, X-inefficiency may lead to programs not performed at least cost. Also, incentives within bureaucracies may create agency problems, which in an innovation context may result in programs implemented above the most efficient least cost method. This is especially problematic in innovation where the private sector is already likely risk averse so that government need to be risk-seeking to avoid crowding out private investment. Their lack of participation in the marketplace may also give governments poor access to information, for example about pricing, competing technologies, and consumer preferences. Finally, decentralized government decision making - in which countries and sub-national governments make independent decisions - inadequate information, poor coordination, and inefficient duplication of programs raise implementation challenges.

\subsubsection{How big a problem are government failures?}

While all of these have the potential to weaken the effectiveness of government innovation support, how big is the problem? A high profile strand of the literature argues that government failures are large, and further that they dominate the market failures. This strong version of the government failures argument implies that even if market failures exist in the valley of death, they are not 
worth addressing because governments don't have the capacity to address them effectively. Social welfare is actually higher by allowing market failure to exist than be implementing remedies. The closest we have in the literature to an empirical assessment of these claims comes from a book consisting of case studies of government demonstration programs (Cohen and Noll, 1991). The authors found problems in nearly every case study, with the exception of the U.S. photovoltaics program. They concluded that:

"American political institutions introduce predictable systematic biases to $\mathrm{R} \& \mathrm{D}$ programs so that on balance, government projects will be susceptible to performance underruns and cost overruns." (Cohen and Noll, 1991)

Their explanation for these biases are all government failure arguments. Governments do not have the information and expertise that the private sector has, so governments make bad allocation decisions. Incentives in bureaucracy are likely highly risk averse which leads them to crowd out private sector investment. Most centrally they find that large projects lead to concentrated interest groups that make the projects difficult to end once started. Cohen \& Noll characterize these dynamics as the 'technology pork barrel,' i.e. government demonstration programs are not managed with the objective of coupling technical and market opportunities, but rather are simply the results of politicians trading favors with each other in an effort to secure as much funding for their constituencies as possible with a focus on the near term.

\subsection{2 'Governments should not pick winners'}

While the Cohen \& Noll arguments were focused on the U.S., they coalesced with a more international discourse about industrial policy in the 1970s and early 1980s (Lindbeck, 1981; Grant, 1982) that claimed that 'governments cannot'- 
and later more normatively that 'governments should not'- 'pick winners." Nelson and Langlois (1983) applied these arguments in an innovation context looking back at their own case studies and found that a policy in which the "government attempts to 'pick winners' in commercial applied R\&D, has been a clear cut failure." The cases they use are similar to those in Cohen \& Noll, and focus on the most high profiles failures, the U.S. supersonic transport program, as well as its European equivalent, the Concorde. The U.S. Synthetic Fuels Corporation also features prominently. Their causal explanations rest on the complexity of the process of innovation and the "location of knowledge and the mechanism of its transmission in the R\&D system." Governments simply are not able to access and make use of information as well as the private sector can.

Accepting these claims would have important implications for future technologies. If the government failures depicted in the technology pork barrel are inherent to government technology programs, and if certain technologies face a valley of death at the demonstration phase, then perhaps we should stop consideration of the possible future availability of those technologies. Or at least, we should leave that to other governments that somehow overcome the pork barrel problems or ignore the inefficiencies associated with overcoming the valley of death.

\subsubsection{Reassessing failure}

Looking back on this work, with multiple decades of hindsight, what is most striking is how difficult it is to distinguish a technology failure from a policy failure. The studies above tend to conflate the two; if a technology fails to become widely adopted, that provides evidence that the government program supporting it was a mistake. Quantifying the waste is a straightforward process of tallying the project's expenditures.

But we know that the returns to innovation investments are highly skewed, 
with a few in the money bets offsetting many more losers (Scherer and Harhoff, 2000). Investing in technology requires a portfolio approach to manage risk and address unknowable ex ante outcomes (Anadon et al., 2016). A recent reassessment of one of the central justifications for the technology pork barrel and the problems with picking winners - the U.S. Synthetic Fuels Corporation-found that the core reason for the 'failure' was the crash in global oil prices in the fall of 1985 (Anadon and Nemet, 2014). Several of the funded projects were completed on time and within budget; the technology performed so well that the core gasifier technology became widely used in China; and some have even argued that the potential for synthetic fuels influence the OPEC decisions to increase production and drop prices. The technology did not achieve its goal of offsetting $1 / 3$ of U.S. oil imports by 1992, but with cheap oil that goal was abandoned. If the program is seen as a $\$ 6 \mathrm{~b}$ insurance policy against the cost of the widely expected doubling in the price of oil (EIA, 2008) it is not clear that it was such a failure. Nor is it clear that the U.S. government had worse information and handling of it than did the private sector. The modern day equivalent of Synthetic Fuels is Solyndra, a manufacturer of photovoltaics that received $\$ 0.5 \mathrm{~b}$ in government loans to produce solar panels with less silicon. When the price of silicon crashed the company went bankrupt. Like oil in 1985, there were not many who were anticipating the crash in the price of silicon, and thus solar, in that period (Curtright et al., 2008). In an appropriately titled "Should We Give Up After Solyndra?" work on R\&D portfolios, Webster et al. (2015) even find that poor performance early on is not sufficient evidence to justify program cancellation. Weyant (2011) provides an interesting interpretation of the valley of death problem: "the problem seems to be one of too few births and too many infants who need help breathing, not one of too many deaths." 


\section{Approach and data}

To evaluate past demonstration projects, we investigate how public innovation support mechanisms can maximize the effectiveness of government support to overcome the valley of death, by analyzing past cases of large scale demonstration projects. We examine 511 cases in 9 technology areas over the past several decades, coding each demonstration project on the factors described in more detail in the next section. Given that all are part of a portfolio, we do not attempt to classify each as a success or failure. Rather we assemble a data set of characteristics of each and focus on evaluating what we do know from the literature about important attributes of government support for innovation at the demonstration stage. For example, we know that program design can enhance the likelihood of achieving overall objectives by: willingness of private sector to assume significant share of costs (Frishammar et al., 2015), engaging users (Schot et al., 2016), establishing clear participant responsibilities and project objectives, allowing for continuous experimentation, including interim failures and iteratively responding to mistakes (Leoncini, 2016), and plans for codification and effective reporting of results (Grubler and Nemet, 2014). Using these and other claims from the literature about demonstration projects, we develop hypotheses for several characteristics, which we code for each project.

\subsection{Coding of case studies}

Given the innovation market failures associated with the valley of death and the perception of a poor record of government performance epitomized by the technology pork barrel, our motivating question is: how can public support for technology demonstration projects be structured to be most effective? We address this question by systematically characterizing each previous projects in six areas which the literature has pointed to as important to creating new knowledge, i.e. 
learning.

1. Timing: Iteration enables learning and technology improvement (Wright, 1936; Sheshinski, 1967). Sequential construction of projects allows for opportunities from learning by doing; knowledge generated in producing one demonstration can be used to inform subsequent plants. Iteration enables successful learning by allowing for responses to failure (Frishammar et al., 2015) and thus enhancing the ability to assume and manage risk. Further iteration allows for a progression of technical to organizational to market learning (Bossink, 2015). We code the timing of each project by the year the project was begun, when it became operational, and when it ended.

3. Motivation: Demonstration projects are undertaken to achieve diverse social goals. More immediately the projects themselves may be undertaken with varied motivations that affect their success. An important distinction is between projects meant to serve as exemplars to encourage commercialization or as experiments from which to learn (Frishammar et al., 2015). Strong arguments that emphasize that the real social value is in learning rather than in proving (Reiner, 2016). Still other motivations exist, e.g. given the large public funds being used, they are often used to pursue a social goal itself, such as production, or environmental benefits. Clarity in communicating these objectives, and participant responsibilities is also important (Harborne and Hendry, 2009). We code each project on the stated motivations including: production, creating knowledge, scale-up, proving technology, and other motivation. The category 'other motivation' includes environmental protection, job creation, and energy independence. These three were the main motivational drivers that we coded as other.

4. Contribution: Typically, some form of public funding is essential for demonstrations (Foxon, 2010). Part of the technology pork barrel argument is 
that the firms see securing government funding as their primary objective and consequently have little incentive to implement projects effectively (Cohen and Noll, 1991). An important development in the past decades has been much more careful consideration of risk and reward for participants (Baer et al., 1976; Dosi et al., 2006; Markusson et al., 2011; Scarpellini et al., 2012; Russell et al., 2012). Crucially, involvement of firms also provides opportunities for experiential learning (Baer et al., 1976; Hendry et al., 2010; Schreuer et al., 2010; Russell et al., 2012) and can stimulate networks of cooperating firms (Bossink, 2015). Success depends on the private sector assuming a large share of both funding and management (Lefevre, 1984; Macey and Brown, 1990). For each project we calculate the total project cost and the public and private sector shares of those costs.

2. Scale: Increasing the scale of plants is a central function of the demonstration phase (Rai et al., 2010; Herzog, 2011; Zhou et al., 2015). Upscaling however involves overcoming obstacles (Rosenberg and Steinmueller, 2013) and consequently takes considerable time (Wilson, 2012). We code each demonstration program by the scale of production, using equivalent units within each technology area. We compare the scales of demonstration plants to full commercial scale.

5. Knowledge dissemination: While generating new knowledge is a central objective, the social benefits of public investment in demonstrations also depend on codifying and disseminating that knowledge (Peters et al., 2012; Bednyagin and Gnansounou, 2012; Cappelli et al., 2014). Effective reporting of results is central to the public goods that projects provide (Frishammar et al., 2015), especially in that it allows for performance review (Thomsen et al., 2005). But firms have incentives to make the new knowl- 
edge proprietary (Lefevre, 1984) and lack of codification can lead to its depreciation (Grubler and Nemet, 2014). We aimed to track instances of technical improvement, codification, dissemination of these projects.

6. Markets: One of the central tenants of the technology pork barrel arguments are that governments are unable to access information about ultimate users (Nelson and Langlois, 1983). Work has emphasized the need to connect demonstration projects to adopters and the markets in which they will ultimately compete (Kingsley et al., 1996; Sun et al., 2014). This importance is bolstered by demand pull arguments about the importance of demand for innovation (Di Stefano et al., 2012) and the particular issues of policy credibility for environmental technologies (Nemet et al., 2014). We connect each demonstration project to market indicators (prices) over time at the technology level. This allows comparing decisions to initiate, operate, and cancel projects with market expectations at the time.

We partially coded other factors but could not obtain information for a substantial portion of the sample. These include information about the structure of government funding, program governance (e.g. use of rules vs. discretion), firm's financing mechanisms, and intellectual property ownership.

\section{2 $\quad$ Selecting case studies}

We evaluate each of these six characteristics for a set of technologies that are analogous to large demonstration plants in low-carbon industry due to similarities in scale, complexity, markets, and integration into a broader technological system. We select analogous technologies from three sectors:

Electricity: 1) solar thermal electricity, 2) nuclear power, 3) wind power, 4) carbon capture and storage (CCS) for power plants;

Industry: 5) CCS for industry, 6) steel, 7) cement; and 


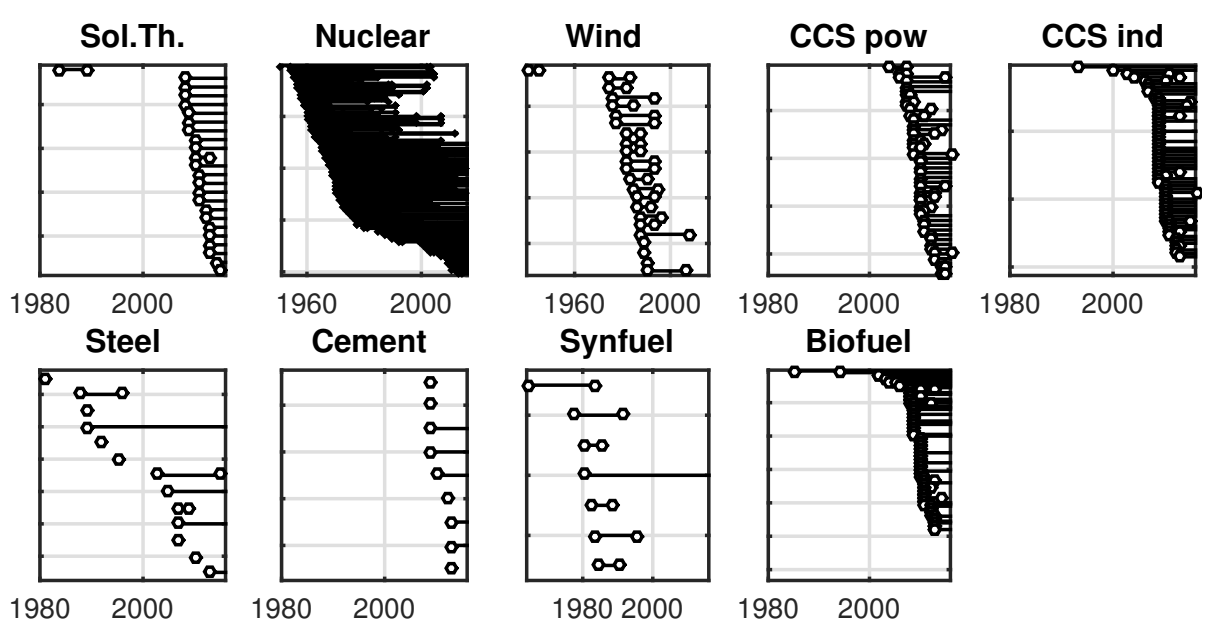

Figure 2: Timing of demonstration projects included in analysis.

Liquid fuels: 8) synthetic fuels, and 9) cellulosic biofuels.

Each case involves a well-documented government effort to demonstrate the technology, e.g. wind power (Gipe, 1995), CCS (Herzog, 2016), and synthetic fuels (Anadon and Nemet, 2014).

We identify demonstration projects in each of these technologies. Using the general definition of demonstrations by Frishammar et al. (2015) above we search for projects for which: 1) there is an element of novelty, e.g. a firstof-a-kind, or nth-of-a-kind, 2) development is advanced enough that scale and maturity are beyond the laboratory and prototype stage, e.g. operating in a real environment, but 3) not yet commercially available, e.g. for sale to a third party. The resulting set of 511 cases across the nine technology areas spans start dates from 1940-2015 (see Figure 2). The supporting information (SI) has additional detail on the cases, including a list of them.

\section{Characteristics of previous demonstrations}

Based on coding these demonstration projects, we report: timing and scale-up; project motivations; private sector contributions; documentation of performance 
improvement; and connections to markets.

\subsection{Timing}

As shown in Figure 2, the projects span a 75 year period. Having coded the project start, completion, and cancellation dates (see table in SI), we found the following: Average time from beginning of a project to coming on-line was 1.9 years for all projects, highest in CCS power plants and synfuels. In contrast to prominent literature on commercial plants, nuclear demonstrations were only slightly above the average (2.5 years), although it also had the most variation. For all projects, $36 \%$ were cancelled, with the highest cancellation rate in nuclear power plants. For nuclear, we considered lifetimes of $<30$ years as cancellations rather than end of life shutdowns. For projects that were cancelled, the average time on-line before project cancellation was 11.4 years. Of the projects that were ultimately cancelled, $27 \%$ were cancelled before they ever came on-line. For the projects that were cancelled after they came on-line, average time to complete construction was 5.3 years, more than double the mean construction time.

\subsection{Motivation}

Table 1 shows the motivations expressed by each project that we were able to code. We arrange the motivations in terms of timing of impact: the most near term focused objective is to produce a product while the most long term would be to learn, which serves a broader goal (such as production) in the longer term. In aggregate, the four categories are at quite similar levels. However, the technology specific mixes are quite distinct. Steel, cement, and synthetic fuels have prioritized learning in more than half of the projects. Scale up has been important for wind, cement, and synfuels; proving technology for power plant CCS, steel, and cement. More than half of projects in power plant CCS, 


\begin{tabular}{lrrrrrr}
\hline Technology & Production & Proving & Scale up & Learning & Other & $\mathrm{N}$ \\
\hline 1) Sol. Th. Elec. & $29 \%$ & $33 \%$ & $21 \%$ & $17 \%$ & $29 \%$ & 24 \\
3) Wind Power & $43 \%$ & $26 \%$ & $78 \%$ & $13 \%$ & $0 \%$ & 23 \\
4) CCC Power & $52 \%$ & $64 \%$ & $45 \%$ & $50 \%$ & $25 \%$ & 44 \\
5) CCC Industry & $29 \%$ & $40 \%$ & $31 \%$ & $34 \%$ & $19 \%$ & 62 \\
6) Steel & $46 \%$ & $62 \%$ & $38 \%$ & $54 \%$ & $15 \%$ & 13 \\
7) Cement & $56 \%$ & $89 \%$ & $67 \%$ & $89 \%$ & $33 \%$ & 9 \\
8) Syn. fuels & $56 \%$ & $56 \%$ & $56 \%$ & $56 \%$ & $44 \%$ & 7 \\
9) Cell. biofuels & $6 \%$ & $12 \%$ & $6 \%$ & $13 \%$ & $2 \%$ & 126 \\
\hline All Sectors & $27 \%$ & $34 \%$ & $28 \%$ & $29 \%$ & $14 \%$ & 308 \\
\hline
\end{tabular}

Table 1: Stated motivations in demonstration projects ( $>1$ response possible per project).

cement, and synfuels see production as a motivation. We note that projects in some cases stated more than one motivation so that they sum to more than 100\%. Figure 11 shows trends in motivation. We do not notice any distinct shift, although we note a broader mix of motivations (and thus lower shares for all) toward the end of the time period.

We approached this question with the prior hypothesis that projects tend to overemphasize production as an objective, at the expense of learning. The results we have found do not provide support, the shares of motivations are quite similar, at least across all projects. We note that solar thermal electric, biofuels, and wind power have been least focused on learning as a motivation. This result fits with the prominence of demand pull policy instruments for these technologies, as well as below-median levels of public investment, which we discuss next (Figure 3). One possible explanation is some selection in terms of which cases provided information on motivations; we have motivation information for $60 \%$ of the cases. A second possibility is related to the option of multiple responses. In a secondary analysis we weighted the responses inversely by the number of objectives provided, e.g. each motivation weighted by $1 / 4$ if four motivations were provided. In that case we see mainly similar outcomes with the additions that: production is important for wind power and proving technology is important for industrial CCS. 

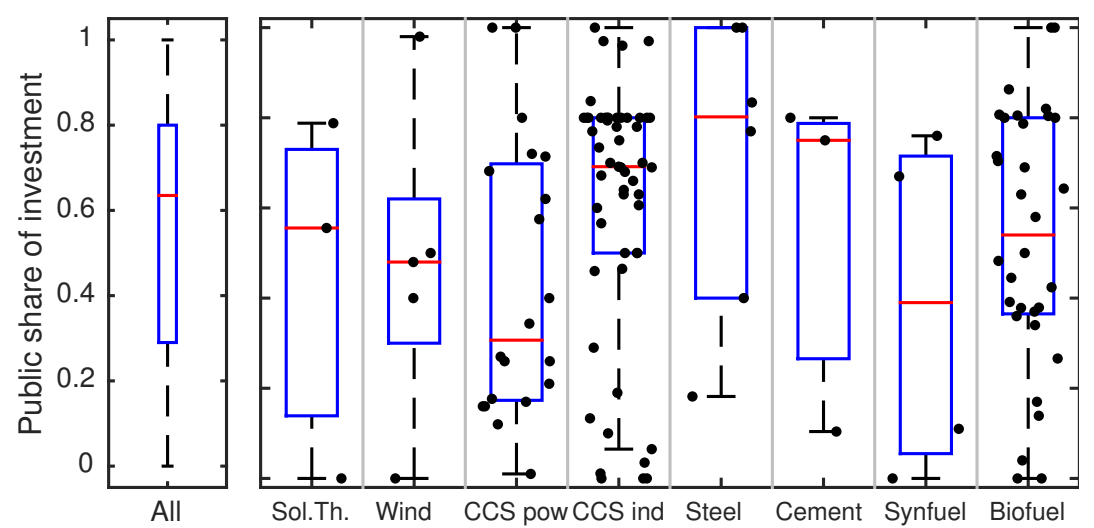

Figure 3: Contributions of public sector to demonstration projects included in analysis. Boxes represent $25-75$ th percentile ranges, red line is median, and dashed lines indicate full range.

\subsection{Public contribution}

In Figure 3 we show the public share of expenditures for each project for which we could obtain data. Across all projects we see a median public contribution of $64 \%$, with a $25-75$ th percentile range of 29-80\%. Every technology area shows a wide dispersion in public contribution, with many including both completely publicly and completely privately funded projects. Notably we see substantially higher public sector participation in industrial CCS projects compared to powersector CCS; the 25-75 ranges do not overlap. We note that some firms may be in a regulated environment that allows them to pass on all or some of their share to ratepayers (Averch and Johnson, 1962). However, even in the power sector in a single country there is inconsistent treatment of cost recovery in these projects so we do not attempt to code them in this way.

To explore some of the possible factors affecting this wide dispersion, Figure 4 shows bivariate comparisons of public share with: start year, sequence, budget, and market prices in which the technologies would ultimately compete. Note that this figure does not include data on nuclear projects where data on the public share was unavailable. Linear fits show only weak relationships, e.g. 

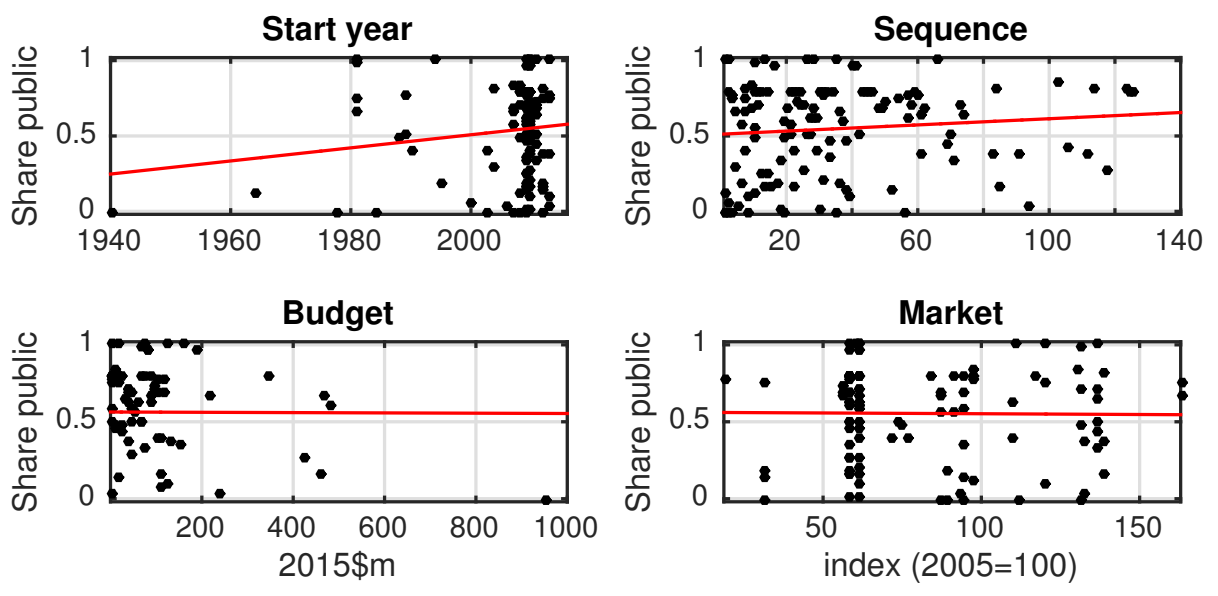

Figure 4: Contributions of private sector to demonstration projects included in analysis. Horizontal axes show: year project began, nth plant for each technology, total project budget, and price index for relevant market

there appears to be a trend toward higher public share. Notably there are very little indications of a relationship between project size (in terms of budget) or in terms of prices. To further assess these possible relationships, we also estimated the determinants of the public sector share of public funding using fractional logit models. We do not find any significant results, although the budget coefficient is negative and slightly significant at the ten percent level in two out of seven estimations. We note that we have only full data for about 100 observations, and we are careful to include 8 technology dummies in every estimation, so there is some risk of a type II error. Nonetheless it is somewhat surprising to see no effect of public share given the large range of project budgets included and the notion that scale affects incentives. We include these results in the SI.

\subsection{Upscaling}

Looking at the size of projects within a technology area over time, it is clear that upscaling is a central outcome. In every case, one can see a trend to larger projects over time (Figure 5). We selected these nine technology areas in part 
based on the technologies needing to function at large scale to be commercially viable. Yet, there is no case in which demonstrations were built at a commercial scale at the beginning. We know that the process of upscaling takes years and involves iterative improvement (Wilson, 2012), and that is certainly the case with these projects. For a closer look, consider the example for which we have comprehensive data over 65 years, nuclear fission power plants (Figure 6). It took 15 years to go from the first demonstrations to commercial scale plants; and that is for the technology that has been deployed more rapidly than any other. One sees a similar pattern in wind turbines. In that case, it was quite clear in the early 1970s that wind turbines would need to be built at MW scale to be economically competitive (Vargo, 1974). As a result, the U.S. and Germany developed several demonstrations at $>1 \mathrm{MW}$ using technology from the aerospace industry (Gipe, 1995). Yet, these approaches failed compared to the Danish approach which was to gradually upscale their turbines, so that it took over 20 years to reach $1 \mathrm{MW}$ scale. The Danish approach of gradual upscaling with iterative improvement led them to dominate the wind power industry (Garud and Karnoe, 2003).

\subsection{Performance}

We were unsuccessful in obtaining performance data for anything close to a representative sample of the projects we coded. On one hand this means we cannot make claims about performance data. On the other hand, that we made a reasonable attempt and failed, could be due to the lack of performance data that has been made publicly available. It is striking how little is available. As an exception, we show the results from the first solar thermal electricity plants in California in the 1980s (Figure 7). These results show impressive cost reductions over sequential plants, including scale-up. Perhaps even more relevant to this paper is that we are only able to observe this improvement due to a 50:50 cost 

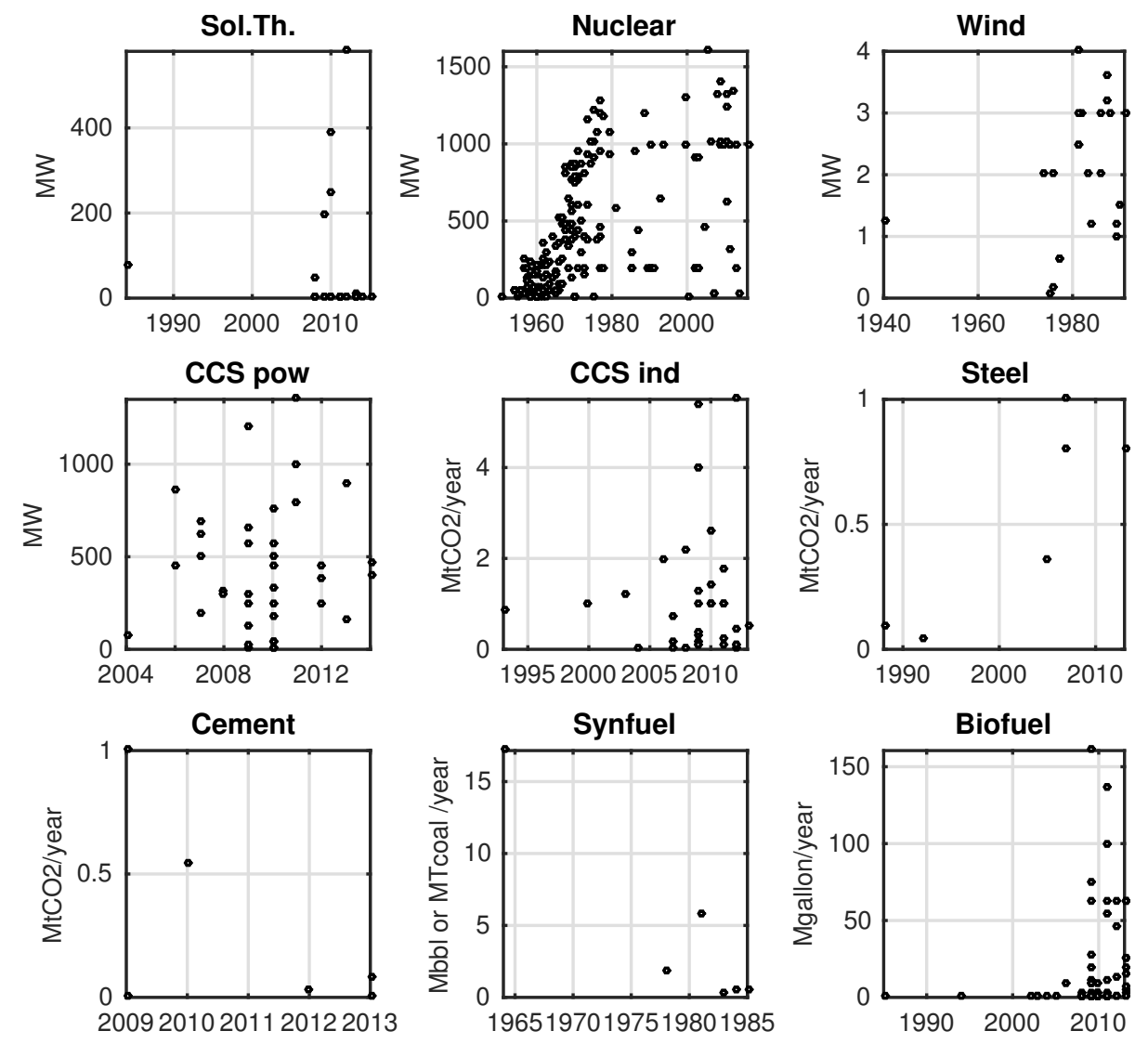

Figure 5: Scale of demonstration projects by project start year. 


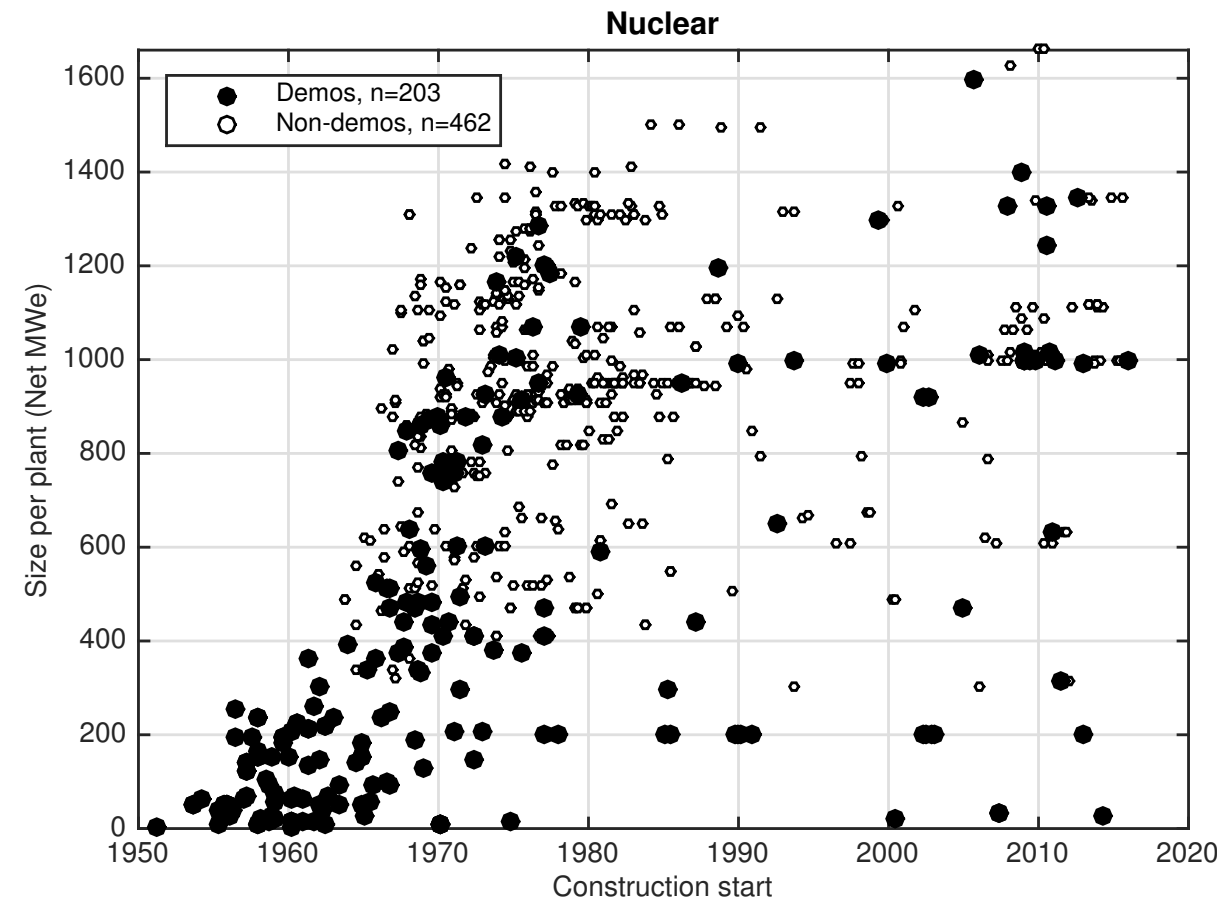

Figure 6: Nuclear power plants: scale of demonstration projects compared to commercial plants (non-demos). Demonstrations defined as: 1) first of a kind reactor type by supplier, 2) built at $<50 \%$ of minimum commercial scale $(500 \mathrm{MW})$, or 3$)$ operating for $<25 \%$ of 60 year life. 


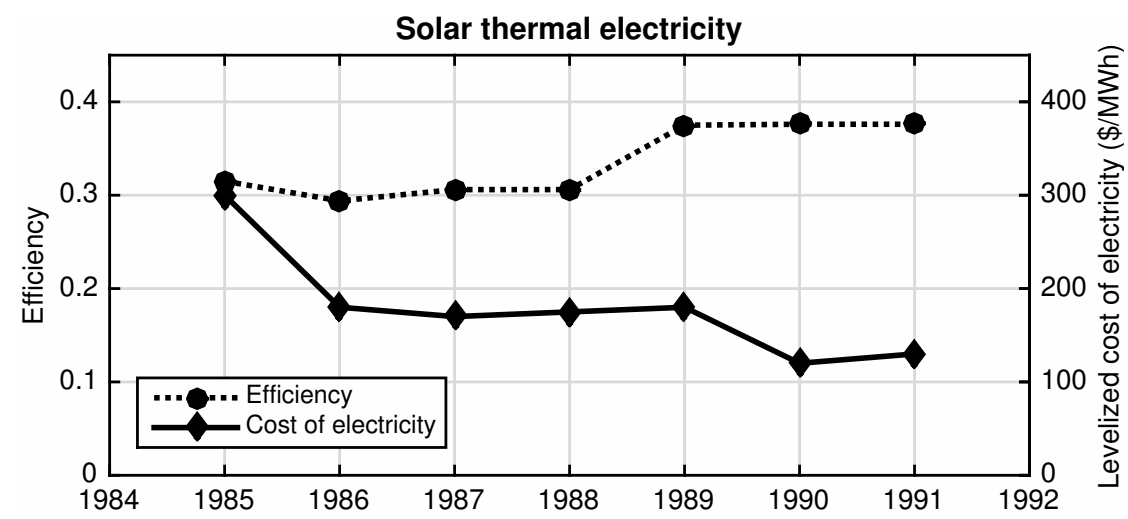

Figure 7: Performance of solar thermal electricity demonstration projects.

shared post-demonstration assessment by the private firm who developed the plants and the U.S. Department of Energy (Nemet, 2014). Performance was assessed systematically over time and made publicly available (Lotker, 1991). From the projects we have reviewed, this post-project assessment represents the gold standard for knowledge codification and dissemination for demonstration plants.

\subsection{Markets and expectations}

To assess the markets in which these demonstration projects were ultimately to compete, we create price indices for each of the markets in which each of these 9 technologies competes (Figure 8). Prices are in real dollars and indexed so that $2005=100$. In addition, we add a Hotelling curve using a typical social discount rate of $3 \%$ to give a sense of the general expectation of a long term price path for a non-renewable resource (Hotelling, 1931). This descriptive comparison supports what is clear from the literature (Krautkraemer, 1998; Zaklan et al., 2011), that price paths following Hotelling are the exceptions rather than the rule. It is important to consider that Hotelling is not merely an academic construct, it shapes expectations about future prices in a variety of contexts. Our data suggests that relying on a Hotelling path for future payoffs is a risky 

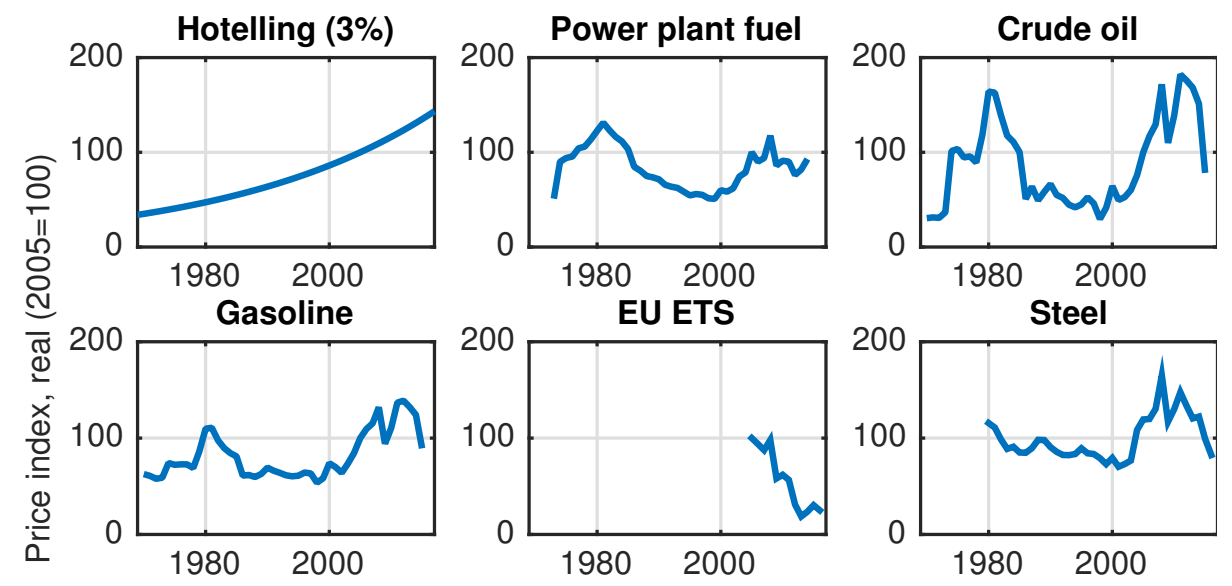

Figure 8: Price indices for markets relevant to each technology

bet.

Looking at market prices in the context of previous demonstrations shows a recurring outcome; demonstration project often come on-line just as markets for them are heading in the wrong direction. The projects were planned when prices and expectations rose, and only came on-line when prices crashed. The lags between project initiation and on-line make them vulnerable to volatile markets. We see this clearly in synfuels (Figure 9), in which projects came on-line just as the market was disappearing. We see similar outcomes in solar thermal electricity and cellulosic biofuels. In the synfuels case, only one project survived; this more than any other outcome led to the notion of the technology pork barrel. It was not that technology did not perform according to projections, but the unexpected drop of global oil prices that eliminated the commercial viability of the projects. This outcome created the impression of a failure of the innovation policy.

CCS projects show a similar pattern; projects have come on-line just as the EU ETS price has crashed (Figure 10). Taking a more future oriented perspective, we also plot expectations of future carbon prices in 2030 (Usher and Strachan, 2013; Kalkuhl et al., 2016). We see expectations of higher prices than 
Solar thermal electricity
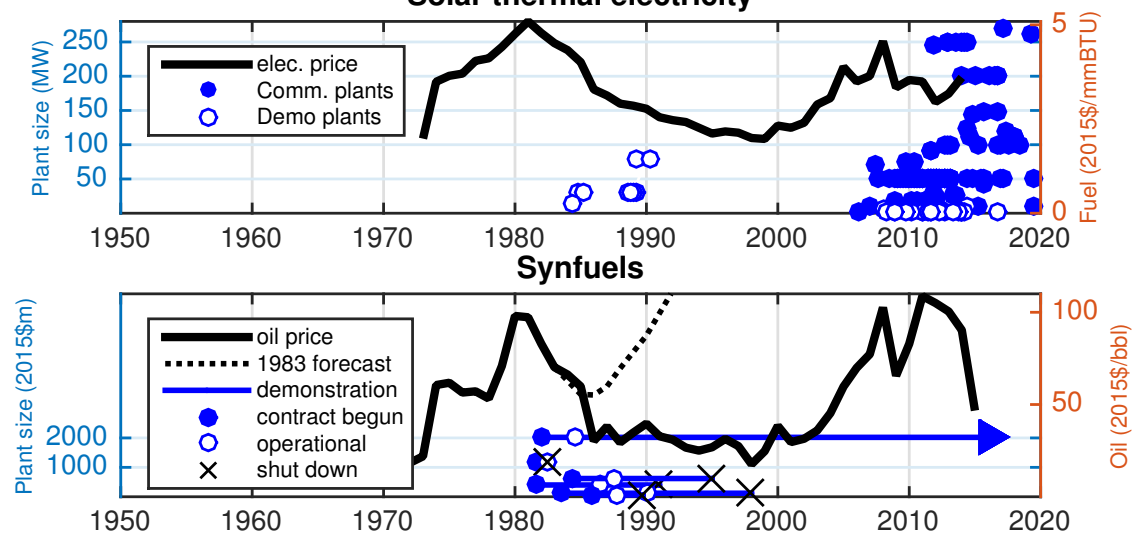

Biofuels

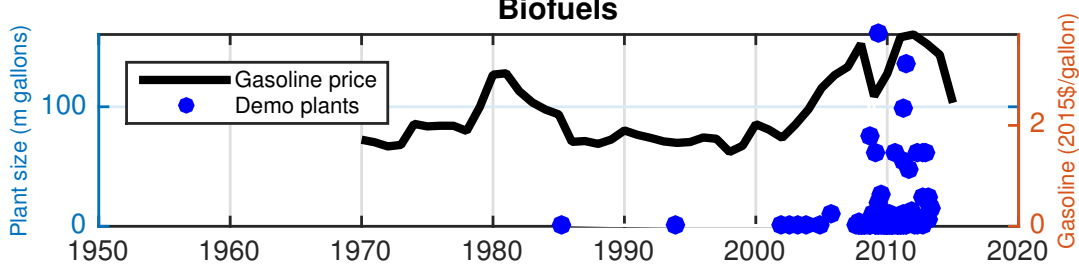

Figure 9: Markets for demonstration projects: solar thermal electric, synthetic fuels, and cellulosic biofuels.

currently, but also wide dispersion implying considerable uncertainty, even as to whether prices will be higher or lower than today's. It seems possible that CCS markets could look similar to those of synfuels and others, such that projects coming on-line may need to survive multiple years selling into a low price regime before prices rise. The persistent pattern of unstable energy markets suggests that demonstration programs need a plan for robustness, so that projects have a chance to proceed to commercial adoption under a range of market outcomes, not just optimistic ones. 

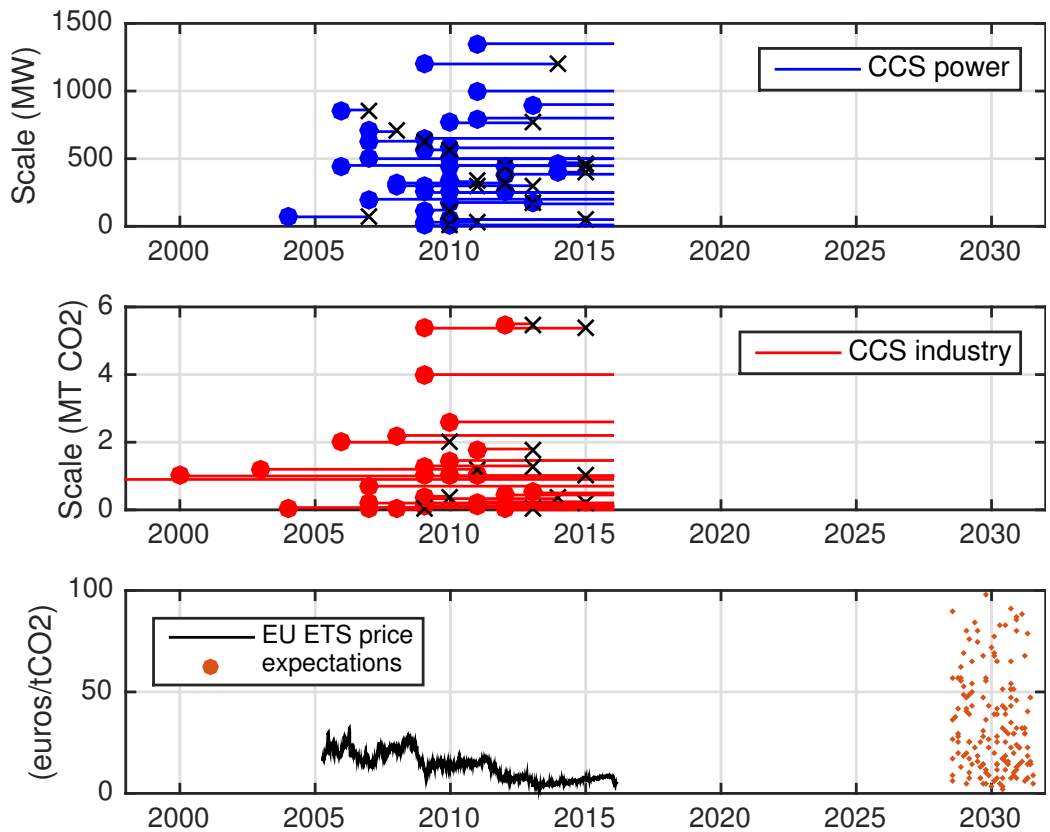

Figure 10: Markets for demonstration projects in CCS.

\section{Discussion and conclusion}

Looking at a a broad set of previous demonstration projects provides insights for how to make the most out of future government support for demonstrations.

\subsection{Prioritizing learning and tolerating failures}

A broad set of literature discusses the benefits of clarifying program objectives (Harborne and Hendry, 2009) and making sure 'learning' is a prominent one (Reiner, 2016). Consequently, appropriate metrics for project selection or continuation are unlikely to be in terms of performance or cost per performance, which was a problem in NER300, a previous CCS demonstration solicitation (Lupion and Herzog, 2013). Rather goals should focus on maximizing learning or minimizing cost per learning. Production and costs are useful indicators of progress but are not worthy goals on their own, as they can often be achieved by avoiding risk and minimizing technical diversity, both of which inhibit learning. 
Milestone payments provide help in this direction. To be sure, they raise the importance of defining meaningful milestones. If milestones were to be based on knowledge created, that would certainly be a promising direction.

Historically, many demonstration programs have been motivated by a larger social goal, which results in government goals that are much more production oriented, e.g. $20 \mathrm{~m}$ gallons of biofuels, $2 \mathrm{~m}$ bpd of synfuels, or 100 nuclear reactors. These goals create a form of demand pull, but by themselves they do not reveal whether projects might determine that the technology is infeasible, unreliable, too expensive, or too immature for commercial adoption. Our review of past projects identified a wide range of motivations. More exemplar oriented items like "production" and "proving" were found at about the same rate as more learning oriented ones such as "up-scaling" and "learning." There was no significant trend over time in the occurrence of each motivation (Figure 11).

In short, demonstrations are best seen as experiments (Lefevre, 1984), part of a process of continuous experimentation (Hellsmark, 2010). Risk and failure are crucial to learning (Anadon et al., 2016). This set of activities is not the place for governments to be risk averse. Rather, we need to make mistakes not just to improve chances of hits, but also to learn from what did not work (Grubler and Wilson, 2014). Only $60 \%$ of the projects for which we could obtain motivation information stated something related to learning as an explicit objective To enhance the social returns of these government investments, all of them should consider learning as part of their objectives at the very least. They thus should be monitored and reported on to facilitate learning.

\subsection{Iterative upscaling and supporting diversity}

Given learning as a prime objective, the programs of the past make clear that there are benefits to sequential iteration to enhance learning. Previous work has shown that a sequence of technical, organizational and market demo is 
needed (Bossink, 2015). Further, demonstration plants are tools for upscaling (Frishammar et al., 2015), which takes time, and requires passing through a 'formative phase' of experimentation (Wilson, 2012). More bluntly it is clear that building to full commercial size immediately is asking for trouble, as we've seen in wind (Garud and Karnoe, 2003) and to some extent in CCS (Lupion and Herzog, 2013). In contrast, our data show achieving full commercial scale took considerable time (Figure 5). For example, one can clearly see two decades of demonstrations and upscaling in nuclear (Figure 6). That may be an extreme example given the complexity of that technology. Still, it points to the need for sequencing and iterative learning, and perhaps most importantly, some urgency in initiating projects.

The strong effects of scale economies for these technologies also imply a need for diversity support (Markusson et al., 2012) to avoid lock in (Shackley and Thompson, 2012). Given multiple pathways available for large scale low carbon technologies, premature focus can be risky (Nemet et al., 2013). This creates a need to support variety while evolutionary mechanisms impose selection pressure (Kemp et al., 1998).

\subsection{Engaging the private sector}

The presence of knowledge spillovers mean public funding is needed (Foxon, 2010), but we also need private participation (Macey and Brown, 1990). Experiential learning, in which knowledge is created by participants, mean that the private sector must play an active role (Hendry et al., 2010). Coalitions of supportive private actors can create advocacy coalitions that support further efforts at commercialization (Klitkou et al., 2013), although the warning of the technology pork barrel is that they can go too far, and even crowd out earlier stage technologies (Lupion and Herzog, 2013). A central aspect of managing this intersection involves sharing risk (and rewards) between public and private 
(Baer et al., 1976; Markusson et al., 2011). We found a very heterogenous mix of public-private contributions (Figure 3).

\subsection{Disseminating knowledge}

A focus on learning means that management of knowledge is central; how it is produced but also how it is codified, stored, and transmitted (Grubler and Nemet, 2014). Dissemination is even more important given the global public good aspect (atmospheric greenhouse gas storage capacity) of the problems to be addressed. Performance review of demonstrations helps (Frishammar et al., 2015), including especially reporting of results (Gallagher et al., 2006). That was crucial for solar thermal electricity (Figure 7). Notably, those plants were completely privately funded. The public role was on markets, guaranteeing prices as well as funding R\&D to go back and review progress. Reiner (2016) mentions that the UK CCS plants benefitted from access to the engineering plans for plants not built. All of this means that $R \& D$ is needed post- and during the demo phase, in part to support knowledge codification, analysis, etc. but also to work on new problems that building at larger scales reveal. It also implies that policymakers must carefully weigh the benefits of knowledge dissemination against private claims of proprietary access to knowledge created. The benefits of widespread access to knowledge created is not something to give up easily in negotiations to secure private funding.

\subsection{Robust demand pull}

Because the ultimate (but not immediate) goal of supporting demonstrations is to facilitate widespread adoption, demand and thus markets are of course key (Kingsley et al., 1996). In climate change, policies are central to those markets (Taylor et al., 2003; Zhou et al., 2015), thus credibility in those policies is also central (Rai et al., 2010; Finon, 2012). But it is striking how many demon- 
stration programs confronted markets that involved negative shocks around the time that projects came on-line - we see it in synfuels, biofuels, and solar thermal electricity (Figure 9), and CCS (Figure 10). The 1.9 year average lag from project initiation to time on-line is crucial. It would be a mistake to assume a Hotelling price path in which prices of an exhaustible resource (e.g. oil, atmospheric storage of $\left.\mathrm{CO}_{2}\right)$ rise at a constant pure rate of time preference. In this case the relevant price is the level at which avoided $\mathrm{CO}_{2}$ emissions are remunerated. Rather the experience of the past suggests we are more likely to see shocks and boom-bust cycles (Krautkraemer, 1998; Zaklan et al., 2011). We see it in our data in the prices related to each demonstration program (Figure 8). Lupion and Herzog (2013) attribute the failure of the NER300 program to stimulate the construction of any CCS projects to 4 factors: competition with renewables, project complexity, low carbon prices, and a combination of fiscal austerity and weak climate policy around the global financial crisis. Note that three of the four problems involved future demand, not the funding structure itself. Demonstrations need markets that pay off innovation investments not just under a steadily increasing Hotelling-style market, but under a broad range of market conditions. Features of robust demand pull include niche markets (Kemp et al., 1998), hedging across jurisdictions (Nemet, 2010), and flexible production (Sanchez and Kammen, 2016). Government price guarantees have played an important role as we have seen on synfuels, solar thermal electricity, and on a smaller scale, photovoltaics.

\subsection{Towards a demonstration strategy}

Our assessment is that these five items explained above are important policy design elements to include as several countries consider how to support innovation for large scale decarbonization. We also acknowledge that policy makers would benefit from resolving uncertainty in a few additional areas. 
Foremost, two very specific questions need answers: 1) How big a demonstration plant should we build? and 2) How many demonstration plants do we need? Our take on the first question is that iterative upscaling implies that the budget should increase over time. For all projects in our data set, the median cost is $\$ 64 \mathrm{~m}$ and the $10-90 \%$ range is $\$ 5$ million to $\$ 2.4$ billion. Other work indicates that each demonstration costs $\$ 1 \mathrm{~b}$ (Reiner, 2016) while others have designed strategies in which a similar amount is divided into 5 to 6 grants of $\$ 200 \mathrm{~m}$ each (IEA, 2011). The second is an even bigger open question (Reiner, 2015). Some have suggested that 5-10 projects are needed (Herzog, 2011), while others have modeled deployment based on 10 projects (Nemet et al., 2015). Clearly an empirically based pathway to commercialization will help inform this decisionmaking.

A second direction is how to consider public acceptance (Krause et al., 2014; Geels et al., 2016). That these projects are industrial scale and typically unfamiliar make them unlikely candidates for favorable and consistent embrace by various publics. Given the need for governments to take risk and tolerate failures, public attitudes are important to understand. If publics are skeptical, interim problems can become high profile failures and create insurmountable setbacks. This is particularly important if taking risks and experimenting. The abrupt ending of CCS deployment in Germany is a cautionary tale, as are early adoption of even apparently benign technologies such as solar water heaters in California (Taylor et al., 2007).

Coming back to the original technology pork barrel argument (Cohen and Noll, 1991), a third direction is to account for the political economy dimensions of demonstration projects. But rather than an interpretation encapsulated in governments should avoid picking winners, here there is an opportunity to think more normatively about how to design programs within a setting of influential political actors (Klitkou et al., 2013). For example, "advocacy coalitions" are 
a promising dimension to understand and address specifically in demonstration program design (Dasgupta et al., 2016)

In short, policy makers need to learn from failures and successes of the past in order to design a demonstration strategy that itself can both generate new knowledge and learn from that which is created.

\section{Acknowledgements}

We are grateful for funding from German Federal Ministry for Economic Affairs and Energy contract \#03MAP316. We received helpful comments during presentations at: DIW-Berlin, Economics for Energy-Madrid, ETH-Zurich, IAEE-Bergen, OECD, SPRU, and the Technical University of Berlin.

\section{References}

Max Ahman, Lars J. Nilsson, and Bengt Johansson. Global climate policy and deep decarbonization of energy-intensive industries. Climate Policy, pages 1-16, 2016. ISSN 1469-3062. doi: 10.1080/14693062.2016.1167009. URL http://dx.doi.org/10.1080/14693062.2016.1167009.

Laura Diaz Anadon and Gregory F. Nemet. The U.S. Synthetic Fuels Corporation: Policy Consistency, Flexibility, and the Long-Term Consequences of Perceived Failures, pages 257-273. Cambridge University Press, Cambridge, 2014.

Laura Diaz Anadon, Erin Baker, Valentina Bosetti, and Lara Aleluia Reis. Too early to pick winners: Disagreement across experts implies the need to diversify r\&d investment. SSRN eLibrary, 2016.

Marlene Arens and Michael Meister. R\&d strategies of co2 intensive industries in an uncertain world the case of the european iron and steel industry. Report, International Association for Energy Economics International Conference, June 20-22 2016 .

W. Brian Arthur. The structure of invention. Research Policy, 36(2): 274-287, 2007. URL http://www.sciencedirect.com/science/article/ B6V77-4MSHT63-1/2/5017b2dc696d6c8bc1b3affa39a09ac1.

Harvey Averch and Leland L Johnson. Behavior of the firm under regulatory constraint. The American Economic Review, pages 1052-1069, 1962. ISSN $0002-8282$. 
Walter S Baer, LL Johnson, and EW Merrow. Analysis offederally funded demonstration projects: Final report, the rand corporation. Report, R-1926DOE, April, 1976.

Christopher F Baum. Stata tip 63: Modeling proportions. Stata Journal, 8(2): 299, 2008. ISSN 1536-867X.

Denis Bednyagin and Edgard Gnansounou. Estimating spillover benefits of large r\&d projects: Application of real options modelling approach to the case of thermonuclear fusion r\&d programme. Energy Policy, 41(0):269-279, 2012. ISSN 0301-4215. doi: 10.1016/j.enpol.2011.10.046. URL http://www . sciencedirect.com/science/article/pii/S0301421511008573.

Anna Bergek, Marko Hekkert, and Staffan Jacobsson. Functions in innovation systems: A framework for analysing energy system dynamics and identifying goals for system-building activities by entrepreneurs and policy makers. Innovation for a low carbon economy: economic, institutional and management approaches, 79, 2008.

Mercedes Bleda and Pablo del Rio. The market failure and the systemic failure rationales in technological innovation systems. Research Policy, 2013. ISSN 0048-7333.

Simone Borghesi, Massimiliano Montini, and Alessandra Barreca. The EU ETS: The PioneerMain Purpose, Structure and Features, pages 1-28. Springer International Publishing, Cham, 2016. ISBN 978-3-319-311869. doi: 10.1007/978-3-319-31186-9_1. URL http://dx.doi.org/10.1007/ 978-3-319-31186-9_1.

BartA G. Bossink. Demonstration projects for diffusion of clean technological innovation: a review. Clean Technologies and Environmental Policy, 17(6): 1409-1427, 2015. ISSN 1618-954X. doi: 10.1007/s10098-014-0879-4. URL http://dx.doi.org/10.1007/s10098-014-0879-4.

V. Bush. Summary of the report to the president on a program for postwar scientific research. Science, 102(2639):79-81, 1945. URL <GotoISI> : //A1945UA52500003.

Riccardo Cappelli, Dirk Czarnitzki, and Kornelius Kraft. Sources of spillovers for imitation and innovation. Research Policy, 43(1):115-120, 2014. ISSN 0048-7333. doi: http://dx.doi.org/10.1016/j.respol.2013.07.016. URL http: //www.sciencedirect.com/science/article/pii/S0048733313001327.

B. Carlsson and R. Stankiewicz. On the nature, function and composition of technological systems. Journal of Evolutionary Economics, 1(2):93-118, 1991. doi: 10.1007/BF01224915. URL http://dx.doi.org/10.1007/BF01224915.

Linda R. Cohen and Roger G. Noll. The Technology Pork Barrel. Brookings, Washington, 1991.

W. M. Cohen, A. Goto, A. Nagata, R. R. Nelson, and J. R. Walsh. R\&D spillovers, patents and the incentives to innovate in japan and the united states. Research Policy, 31(8-9):1349-1367, 2002. ISSN 0048-7333. URL <GotoISI> : //000179836000010. 
A. E. Curtright, M. G. Morgan, and D. W. Keith. Expert assessments of future photovoltaic technologies. Environmental Science \& Technology, 42(24):90319038, 2008. ISSN 0013-936X. URL <GotoISI> ://000261678800009.

Shouro Dasgupta, Enrica De Cian, and Elena Verdolini. The political economy of energy innovation. Report, United Nations University World Institute for Development Economics Research, April 2016.

Amandine Denis-Ryan, Chris Bataille, and Frank Jotzo. Managing carbonintensive materials in a decarbonizing world without a global price on carbon. Climate Policy, pages 1-19, 2016. ISSN 1469-3062. doi: 10.1080/ 14693062.2016.1176008. URL http://dx.doi.org/10.1080/14693062. 2016.1176008.

Giada Di Stefano, Alfonso Gambardella, and Gianmario Verona. Technology push and demand pull perspectives in innovation studies: Current findings and future research directions. Research Policy, 41(8):1283-1295, 2012. ISSN 0048-7333. doi: 10.1016/j.respol.2012.03.021. URL http: //www.sciencedirect.com/science/article/pii/S0048733312000820.

G. Dosi, L. Marengo, and C. Pasquali. How much should society fuel the greed of innovators?: On the relations between appropriability, opportunities and rates of innovation. Research Policy, 35(8):1110 1121, 2006. URL http://www.sciencedirect.com/science/article/ B6V77-4M21SW3-1/2/819b52e95c55e50f8216ddda38a9426a.

EIA. Annual energy outlook retrospective review: Evaluation of projections in past editions (1982-2008). Report DOE/EIA-0640(2008), U.S. Energy Information Administration, 2008.

D. Finon. Efficiency of policy instruments for CCS deployment. Climate Policy, 12(2):237-254, 2012. ISSN 1469-3062. doi: 10.1080/14693062.2011.605702. URL <GotoISI> : //WOS : 000301714500006.

T. J. Foxon. Stimulating investment in energy materials and technologies to combat climate change: an overview of learning curve analysis and niche market support. Philosophical Transactions of the Royal Society a-Mathematical Physical and Engineering Sciences, 368(1923):3469-3483, 2010. ISSN 1364503X. doi: 10.1098/rsta.2010.0106. URL <GotoISI> : //000278942500013.

Chris Freeman. The economics of industrial innovation. The MIT Press, Cambridge, MA, 1974.

Johan Frishammar, Patrik Sderholm, Kristoffer Bckstrm, Hans Hellsmark, and Hkan Ylinenp. The role of pilot and demonstration plants in technological development: synthesis and directions for future research. Technology Analysis \& Strategic Management, 27(1):1-18, 2015. ISSN 0953-7325. doi: 10.1080/09537325.2014.943715. URL http://dx.doi.org/10.1080/ 09537325.2014 .943715 .

J. L. Funk. What drives exponential improvements? California Management Review, 55(3):134-152, 2013. ISSN 0008-1256. doi: 10.1525/cmr.2013.55.3. 134. URL <GotoISI> ://WOS:000318386300007. 
Kelly Sims Gallagher, John P. Holdren, and Ambuj D. Sagar. Energytechnology innovation. Annual Review of Environment and Resources, 31(1):193-237, 2006. doi: doi:10.1146/annurev.energy.30.050504. 144321. URL http://arjournals . annualreviews.org/doi/abs/10.1146/ annurev .energy.30.050504.144321.

R. Garud and P. Karnoe. Bricolage versus breakthrough: distributed and embedded agency in technology entrepreneurship. Research Policy, 32(2):277300, 2003. URL <GotoISI> : //000181014800007.

Frank Geels, Frans Berkhout, and Detlef van Vuuren. Calibrating integrated assessment models for low-carbon energy transitions. Submission to this Special Section of Nature Energy and Nature Climate Change, 2016.

Paul Gipe. Wind energy comes of age. Wiley, New York, 1995. ISBN $047110924 X$.

Benoit Godin and Joseph P. Lane. Pushes and pulls: Hi(s)tory of the demand pull model of innovation. Science, Technology 85 Human Values, 38(5):621654, 2013. doi: 10.1177/0162243912473163. URL http://sth.sagepub.com/ content/38/5/621. abstract.

Robert M. Grant. Government cannot pick winners. Economic Affairs, 3(1): 29-32, 1982. ISSN 1468-0270. doi: 10.1111/j.1468-0270.1982.tb01457.x. URL http://dx.doi.org/10.1111/j.1468-0270.1982.tb01457.x.

Arnulf Grubler and Gregory F. Nemet. Sources and Consequences of Knowledge Depreciation, pages 133-145. Cambridge University Press, Cambridge, 2014.

Arnulf Grubler and Charlie Wilson. Energy Technology Innovation: Learning from Historical Successes and Failures. Cambridge University Press, Cambridge, 2014.

Bronwyn H. Hall, Jacques Mairesse, and Pierre Mohnen. Measuring the returns to R\&D. National Bureau of Economic Research Working Paper Series, No. 15622, 2009. URL http://www.nber.org/papers/w15622http: //www.nber.org/papers/w15622.pdf.

Paul Harborne and Chris Hendry. Pathways to commercial wind power in the us, europe and japan: The role of demonstration projects and field trials in the innovation process. Energy Policy, 37(9):3580-3595, 2009. ISSN 0301-4215. URL http://www. sciencedirect.com/science/article/ B6V2W-4WBH5F5-2/2/589fd6a4b11ffd5d6ddb4ebbba4fab8a.

Hans Hellsmark. Unfolding the formative phase of gasified biomass in the European Union: The role of system builders in realising the potential of secondgeneration transportation fuels from biomass. Chalmers University of Technology, 2010. ISBN 9173854786.

Chris Hendry and Paul Harborne. Changing the view of wind power development: More than "bricolage". Research Policy, 40(5):778-789, 2011. ISSN 0048-7333. doi: 10.1016/j.respol.2011.03.001. URL <GotoISI> ://WOS : 000291518000012. 
Chris Hendry, Paul Harborne, and James Brown. So what do innovating companies really get from publicly funded demonstration projects and trials? innovation lessons from solar photovoltaics and wind. Energy Policy, 38, 2010. ISSN 0301-4215. URL http://www. sciencedirect.com/science/article/ B6V2W-4YYVCVP-2/2/1b4acffaa7d1d87b450f9607cf146ec2.

Howard Herzog. Lessons learned from ccs demonstration and large pilot projects. Working paper, MIT Energy Initiative, Massachusetts Institute of Technology, 2016.

Howard J. Herzog. Scaling up carbon dioxide capture and storage: From megatons to gigatons. Energy Economics, 33(4):597-604, 2011. ISSN 0140-9883. doi: 10.1016/j.eneco.2010.11.004. URL http://www.sciencedirect.com/ science/article/pii/S0140988310001921.

Harold Hotelling. The economics of exhaustible resources. Journal of Political Economy, 39(2):137, 1931. doi: doi:10.1086/254195. URL http: //www. journals. uchicago. edu/doi/abs/10.1086/254195.

P. Hurmelinna-Laukkanen, L. M. Sainio, and T. Jauhiainen. Appropriability regime for radical and incremental innovations. R\&BD Management, 38(3): 278-289, 2008. ISSN 0033-6807. URL <GotoISI> : //000255836200005.

IEA. Technology roadmap carbon capture and storage in industrial applications. International Energy Agency, United Nations Industrial Development Organizations, 2011.

IEA. Energy technology perspectives 2014: Harnessing electricitys potential. Report, International Energy Agency (IEA), May 2014.

Gokul Iyer, Nathan Hultman, Jiyong Eom, Haewon McJeon, Pralit Patel, and Leon Clarke. Diffusion of low-carbon technologies and the feasibility of long-term climate targets. Technological Forecasting and Social Change, 90, Part A(0):103-118, 2015. ISSN 0040-1625. doi: http://dx.doi. org/10.1016/j.techfore.2013.08.025. URL http://www.sciencedirect.com/ science/article/pii/S0040162513002096.

Adam B. Jaffe, Richard G. Newell, and Robert N. Stavins. A tale of two market failures: Technology and environmental policy. Ecological Economics, 54(2-3): 164-174, 2005. URL http://www.sciencedirect.com/science/article/ B6VDY-4FNDS2D-1/2/690e2c76d222f 12a2f2870e1f82c4e3f.

Matthias Kalkuhl, Sabine Fuss, Gregory Nemet, and Jan Steckel. The role of political uncertainty for climate change mitigation. in preparation, 2016.

Rasmus Karlsson. Apres paris: Breakthrough innovation as the primary moral obligation of rich countries. Environmental Science and Policy, 63:170-176, 2016. ISSN 1462-9011.

Ren Kemp, Johan Schot, and Remco Hoogma. Regime shifts to sustainability through processes of niche formation: the approach of strategic niche management. Technology analysis $\mathscr{E}$ strategic management, 10(2):175-198, 1998. ISSN 0953-7325. 
Gordon Kingsley, Barrt Bozeman, and Karen Coker. Technology transfer and absorption: an r\&d value-mapping approach to evaluation. Research Policy, 25(6):967-995, 1996. ISSN 0048-7333. doi: http://dx.doi. org/10.1016/0048-7333(96)00890-6. URL http://www. sciencedirect.com/ science/article/pii/0048733396008906.

Antje Klitkou, Lars Coenen, P Dannemand Andersen, Arne Fevolden, Teis Hansen, Alexandra Nikoleris, and Dorothy S Olsen. Role of demonstration projects in innovation: transition to sustainable energy and transport. In 4th International Conference on Sustainability Transitions, Zurich, page 28, 2013.

Nicolas Koch, Godefroy Grosjean, Sabine Fuss, and Ottmar Edenhofer. Politics matters: Regulatory events as catalysts for price formation under cap-andtrade. Available at SSRN, 2015.

Rachel M. Krause, Sanya R. Carley, David C. Warren, John A. Rupp, and John D. Graham. not in (or under) my backyard: Geographic proximity and public acceptance of carbon capture and storage facilities. Risk Analysis, 3: 529-40, 2014. ISSN 1539-6924. doi: 10.1111/risa.12119. URL http://dx. doi.org/10.1111/risa.12119.

Jeffrey A Krautkraemer. Nonrenewable resource scarcity. Journal of Economic literature, 36(4):2065-2107, 1998. ISSN 0022-0515.

Stephen R Lefevre. Using demonstration projects to advance innovation in energy. Public Administration Review, pages 483-490, 1984. ISSN 0033-3352.

Riccardo Leoncini. Learning-by-failing. an empirical exercise on cis data. Research Policy, 45(2):376-386, 2016. ISSN 0048-7333. doi: http://dx.doi. org/10.1016/j.respol.2015.10.006. URL http://www.sciencedirect.com/ science/article/pii/S0048733315001596.

Assar Lindbeck. Industrial policy as an issue in the economic environment. The World Economy, 4(4):391-406, 1981. ISSN 1467-9701.

Michael Lotker. Barriers to commercialization of large-scale solar electricity: Lessons learned from the LUZ experience. Contractor Report SAND91-7014, Sandia National Laboratories, November 1991.

Monica Lupion and Howard J Herzog. Ner300: Lessons learnt in attempting to secure ccs projects in europe. International Journal of Greenhouse Gas Control, 19:19-25, 2013. ISSN 1750-5836.

Susan M. Macey and Marilyn A. Brown. Demonstrations as a policy instrument with energy technology examples. Science Communication, 11(3):219-236, 1990. doi: 10.1177/107554709001100301. URL http://scx.sagepub.com/ content/11/3/219. abstract.

Nils Markusson, Atsushi Ishii, and Jennie C. Stephens. The social and political complexities of learning in carbon capture and storage demonstration projects. Global Environmental Change, 21(2):293-302, 2011. ISSN 0959-3780. doi: 10.1016/j.gloenvcha.2011.01.010. URL http://www. sciencedirect.com/science/article/pii/S0959378011000112. 
Nils Markusson, Florian Kern, Jim Watson, Stathis Arapostathis, Hannah Chalmers, Navraj Ghaleigh, Philip Heptonstall, Peter Pearson, David Rossati, and Stewart Russell. A socio-technical framework for assessing the viability of carbon capture and storage technology. Technological Forecasting and Social Change, 79(5):903-918, 2012. ISSN 0040-1625.

David Mowery and Nathan Rosenberg. The influence of market demand upon innovation: a critical review of some recent empirical studies. Research Policy, 8(2):102-153, 1979. URL http://www.sciencedirect.com/science/ article/B6V77-45BCNR6-3K/2/c98e82514343d8472bc49a1750c95e74.

David C. Mowery. The changing structure of the us national innovation system: implications for international conflict and cooperation in r\&d policy. Research Policy, 27(6):639-654, 1998. ISSN 0048-7333. doi: http://dx. doi.org/10.1016/S0048-7333(98)00060-2. URL http://www. sciencedirect . com/science/article/pii/S0048733398000602.

L. M. Murphy and P. L. Edwards. Bridging the valley of death: Transitioning from public to private sector financing. Report NREL/MP-720-34036, National Renewable Energy Laboratory, May 2003.

Richard R. Nelson and Richard N. Langlois. Industrial innovation policy: Lessons from american history. Science, 219(4586):814-818, 1983. doi: 10.1126/science.219.4586.814. URL http://science.sciencemag.org/sci/ 219/4586/814.full.pdf.

Gregory Nemet, Michael Jakob, Jan Steckel, and Ottmar Edenhofer. Addressing credibility problems in climate policy. Global Environmental Change, in review.

Gregory F. Nemet. Demand-pull, technology-push, and government-led incentives for non-incremental technical change. Research Policy, 38(5):700-709, 2009. ISSN 0048-7333. URL http://www.sciencedirect.com/science/ article/B6V77-4VNCBWT-1/2/2c5725cc6030fc4a4164d0b8bd351ee2.

Gregory F. Nemet. Robust incentives and the design of a climate change governance regime. Energy Policy, 38(11):7216-7225, 2010. ISSN 0301-4215. URL http://www.sciencedirect.com/science/article/ B6V2W-50T JP4C-2/2/d07d7ef4d17c0758efc8f1776b1ab85c.

Gregory F. Nemet. Technological Improvements in Solar Thermal Electricity in the United States and the Role of Public Policy, pages 165-177. Cambridge University Press, Cambridge, 2014.

Gregory F. Nemet, Erin Baker, and Karen E. Jenni. Modeling the future costs of carbon capture using experts' elicited probabilities under policy scenarios. Energy, 56:218228, 2013. ISSN 0360-5442. doi: http://dx.doi.org/10. 1016/j.energy.2013.04.047. URL http://www.sciencedirect.com/science/ article/pii/S0360544213003587.

Gregory F. Nemet, Peter Braden, Ed Cubero, and Bickey Rimal. Four decades of multiyear targets in energy policy: aspirations or credible commitments? Wiley Interdisciplinary Reviews: Energy and Environment, 3 
(5):522-533, 2014. ISSN 2041-840X. doi: 10.1002/wene.116. URL http: //dx.doi.org/10.1002/wene.116.

Gregory F. Nemet, Erin Baker, Bob Barron, and Samuel Harms. Characterizing uncertainty in the effects of policy instruments on the future costs of carbon capture. Climatic Change, 133(2):155-168, 2015.

Karsten Neuhoff, Andrzej Ancygier, Jean-Pierre Ponssard, Philippe Quirion, Nagore Sabio, Oliver Sartor, Misato Sato, and Anne Schopp. Modernization and innovation in the materials sector: Lessons from steel and cement. Report, German Institute for Economic Research (DIW Berlin Deutsches Institut fr Wirtschaftsforschung e.V.), 2015.

OECD. Greening steel: Innovation for climate change mitigation in the steel sector. Report, Organization for Economic Cooperation and Development (OECD), 2015.

Leslie E Papke and Jeffrey Wooldridge. Econometric methods for fractional response variables with an application to $401(\mathrm{k})$ plan participation rates. NBER, 1993.

Keith Pavitt. Sectoral patterns of technical change - towards a taxonomy and a theory. Research Policy, 13(6):343-373, 1984. URL <GotoISI> : //A1984AAR4300002.

Michael Peters, Malte Schneider, Tobias Griesshaber, and Volker H. Hoffmann. The impact of technology-push and demand-pull policies on technical change does the locus of policies matter? Research Policy, 41(8):12961308, 2012. ISSN 0048-7333. doi: 10.1016/j.respol.2012.02.004. URL http: //www.sciencedirect.com/science/article/pii/S0048733312000376.

Varun Rai, David G. Victor, and Mark C. Thurber. Carbon capture and storage at scale: Lessons from the growth of analogous energy technologies. Energy Policy, In Press, Corrected Proof(38):40894098, 2010. ISSN 0301-4215. URL http://www.sciencedirect.com/science/article/ B6V2W-4YV7R10-1/2/99f571f62f19c41da56d57b1ca534130.

David M Reiner. Where can i go to see one? risk communications for an imaginary technology. Journal of Risk Research, 18(6):710-713, 2015. ISSN 1366-9877.

David M. Reiner. Learning through a portfolio of carbon capture and storage demonstration projects. Nature Energy, 1:15011, 2016. doi: 10.1038/nenergy. 2015.11. URL http://dx.doi.org/10.1038/nenergy.2015.11.

Joeri Rogelj, Michiel Schaeffer, Malte Meinshausen, Reto Knutti, Joseph Alcamo, Keywan Riahi, and William Hare. Zero emission targets as long-term global goals for climate protection. Environmental Research Letters, 10(10): 105007, 2015. ISSN 1748-9326.

Nathan Rosenberg and W Edward Steinmueller. Engineering knowledge. Industrial and Corporate Change, page dts053, 2013. ISSN 0960-6491. 
Stewart Russell, Nils Markusson, and Vivian Scott. What will ccs demonstrations demonstrate? Mitigation and Adaptation Strategies for Global Change, 17(6):651-668, 2012. ISSN 1381-2386.

Devendra Sahal. Technological guideposts and innovation avenues. Research Policy, 14(2):61-82, 1985. URL http://www.sciencedirect.com/science/ article/B6V77-485R9MX-1/2/109ad867efcf648a5777c6ae899ebb70.

Daniel L Sanchez and Daniel M Kammen. A commercialization strategy for carbon-negative energy. Nature Energy, 1:15002, 2016. ISSN 2058-7546.

Sabina Scarpellini, Alfonso Aranda, Juan Aranda, Eva Llera, and Miguel Marco. R\&d and eco-innovation: opportunities for closer collaboration between universities and companies through technology centers. Clean Technologies and Environmental Policy, 14(6):1047-1058, 2012. ISSN 1618-954X.

F. M. Scherer and D. Harhoff. Technology policy for a world of skew-distributed outcomes. Research Policy, 29(4-5):559-566, 2000. ISSN 0048-7333. URL $<$ GotoISI $>$ : //000086746700007.

Jacob Schmookler. Economic sources of inventive activity. Journal of Economic History, 22(1):1-20, 1962. URL <GotoISI>://A1962CAB6900001.

Johan Schot, Laur Kanger, and Geert Verbong. The roles of users in shaping transitions to new energy systems. Nature Energy, 1:16054, 2016. doi: 10. 1038/nenergy.2016.54. URL http://dx.doi.org/10.1038/nenergy. 2016 . 54.

Anna Schreuer, Michael Ornetzeder, and Harald Rohracher. Negotiating the local embedding of socio-technical experiments: a case study in fuel cell technology. Technology Analysis \& Strategic Management, 22(6):729-743, 2010. ISSN 0953-7325.

Joseph A. Schumpeter. Capitalism, socialism, and democracy. Harper, New York, London, 2d ed. edition, 1947.

Simon Shackley and Michael Thompson. Lost in the mix: will the technologies of carbon dioxide capture and storage provide us with a breathing space as we strive to make the transition from fossil fuels to renewables? Climatic Change, 110(1):101-121, 2012. ISSN 0165-0009. doi: 10.1007/s10584-011-0071-3. URL http://dx.doi.org/10.1007/s10584-011-0071-3.

Eytan Sheshinski. Tests of the learning by doing hypothesis. Review of Economics and Statistics, 49(4):568-578, 1967.

Varun Sivaram and Teryn Norris. The clean energy revolution. Foreign Affairs, 95(3):16, 2016. ISSN 0015-7120.

P. Spath and H. Rohracher. 'energy regions': The transformative power of regional discourses on socio-technical futures. Research Policy, 39(4):449-458, 2010. ISSN 0048-7333. doi: 10.1016/j.respol.2010.01.017. URL <GotoISI> : //WOS:000277764400002. 
Honghang Sun, Qiang Zhi, Yibo Wang, Qiang Yao, and Jun Su. Chinas solar photovoltaic industry development: The status quo, problems and approaches. Applied Energy, 118:221-230, 2014. ISSN 0306-2619.

Margaret Taylor, Gregory Nemet, Michael Colvin, Loida Begley, Cyrus Wadia, and Tyler Dillavou. Government actions and innovation in clean energy technologies: The cases of photovoltaic cells, solar thermal electric power, and solar water heating, CEC-500-2007-012. PIER project report, California Energy Commission, October 2007. URL http://www.energy.ca.gov/pier/ final_project_reports/CEC-500-2006-053.html.

Margaret R. Taylor, Edward S. Rubin, and David A. Hounshell. Effect of government actions on technological innovation for $\mathrm{SO}_{2}$ control. Environmental Science \& Technology, 37(20):4527-4534, 2003.

David J. Teece. Profiting from technological innovation - implications for integration, collaboration, licensing and public-policy. Research Policy, 15(6): 285-305, 1986. URL <GotoISI> ://A1986G069400001.

Kirsten Engelund Thomsen, Jrgen Munthe Schultz, and Bart Poel. Measured performance of 12 demonstration projectsiea task 13 advanced solar low energy buildings. Energy and Buildings, 37(2):111-119, 2005. ISSN 0378-7788.

Abbott P. Usher. A History of Mechanical Inventions. Harvard University Press, Cambridge, MA, revised edition edition, 1954.

Will Usher and Neil Strachan. An expert elicitation of climate, energy and economic uncertainties. Energy Policy, 61:811821, 2013. ISSN 03014215. doi: http://dx.doi.org/10.1016/j.enpol.2013.06.110. URL http://www . sciencedirect.com/science/article/pii/S0301421513006174.

D.J. Vargo. Wind energy development in the 20th century. NASA Technical Memorandum TM X-71634, NASA, Lewis Research Center, September 1974.

D. Verhoeven, J. Bakker, and R. Veugelers. Measuring technological novelty with patent-based indicators. Research Policy, 45(3):707-723, 2016. ISSN 0048-7333. doi: 10.1016/j.respol.2015.11.010. URL <GotoISI> ://WOS : 000370101900010.

Reinhilde Veugelers. Which policy instruments to induce clean innovating? Research Policy, 41(10):1770-1778, 2012. ISSN 0048-7333.

Jim Watson. Setting priorities in energy innovation policy: Lessons for the uk. Report, Harvard University, Belfer Center, October 2008.

Mort Webster, Karen Fisher-Vanden, David Popp, and Nidhi Santen. Should we give up after solyndra? optimal technology r\&d portfolios under uncertainty. National Bureau of Economic Research Working Paper Series, No. 21396, 2015. doi: 10.3386/w21396. URL http://www.nber.org/papers/w21396.

David L Weimer and Aidan Vining. Chapter 8: Limits to Government Intervention: Government Failures. Routledge, 2015. ISBN 1317345657. 
John P. Weyant. Accelerating the development and diffusion of new energy technologies: Beyond the "valley of death". Energy Economics, 33(4):674682, 2011. ISSN 0140-9883. doi: 10.1016/j.eneco.2010.08.008. URL http: //www.sciencedirect.com/science/article/pii/S0140988310001295.

Charlie Wilson. Up-scaling, formative phases, and learning in the historical diffusion of energy technologies. Energy Policy, 50(SI):81-94, 2012. ISSN 03014215. doi: 10.1016/j.enpol.2012.04.077. URL http://www. sciencedirect. com/science/article/pii/S030142151200393X.

M. Woertler, Felix Schuler, Nicole Voigt, Torben Schmidt, Peter Dahlmann, Hans Bodo Lngen, and Jean-Theo Ghenda. Steel's Contribution to a Lowcarbon Europe 2050: Technical and Economic Analysis of the Sector's CO2 Abatement Potential. Boston Consulting Group, 2013. URL https://books . google. com/books?id=KgR8oAEACAAJ.

T. P. Wright. Factors affecting the costs of airplanes. Journal of the Aeronautical Sciences, 3:122-128, 1936.

Aleksandar Zaklan, Jan Abrell, and Anne Neumann. Stationarity changes in long-run fossil resource prices: Evidence from persistence break testing. Discussion paper, German Institute for Economic Research (DIW), 2011.

Y. Zhou, G. N. Xu, T. Minshall, and P. Liu. How do public demonstration projects promote green-manufacturing technologies? a case study from china. Sustainable Development, 23(4):217-231, 2015. ISSN 0968-0802. doi: 10.1002/ sd.1589. URL <GotoISI>://WOS:000360454500003. 


\begin{tabular}{lrrrrrrr}
\hline Technology & 1.Start & 2.Online & 3.End & col.2-1 & col.3-1 & col.3-2 & \% cancel \\
\hline 1) Sol. Th. Elec. & 2010 & 2012 & 2017 & 2.7 & 6.8 & 4.1 & $1 \%$ \\
2) Nuclear Power & 1974 & 1976 & 1991 & 2.5 & 17.6 & 15.1 & $56 \%$ \\
3) Wind Power & 1981 & 1983 & 1990 & 1.8 & 8.8 & 6.9 & $13 \%$ \\
4) CCS Power & 2010 & 2016 & 2013 & 6.0 & 3.5 & -2.5 & $17 \%$ \\
5) CCS Industry & 2009 & 2011 & 2013 & 2.2 & 4.0 & 1.8 & $6 \%$ \\
6) Steel & 1999 & 2003 & 1996 & 4.0 & -2.9 & -6.9 & $0 \%$ \\
7) Cement & 2011 & 2013 &. & 2.5 &. &. & $0 \%$ \\
8) Syn. Fuels & 1979 & 1985 & 1989 & 5.6 & 9.7 & 4.2 & $3 \%$ \\
9) Cell. Biofuels & 2009 & 2011 & 2012 & 1.8 & 2.7 & 0.9 & $3 \%$ \\
\hline All Sectors & 1992 & 1994 & 1997 & 1.9 & 4.6 & 2.8 & $36 \%$ \\
\hline
\end{tabular}

Table 2: Timing of demonstration projects.
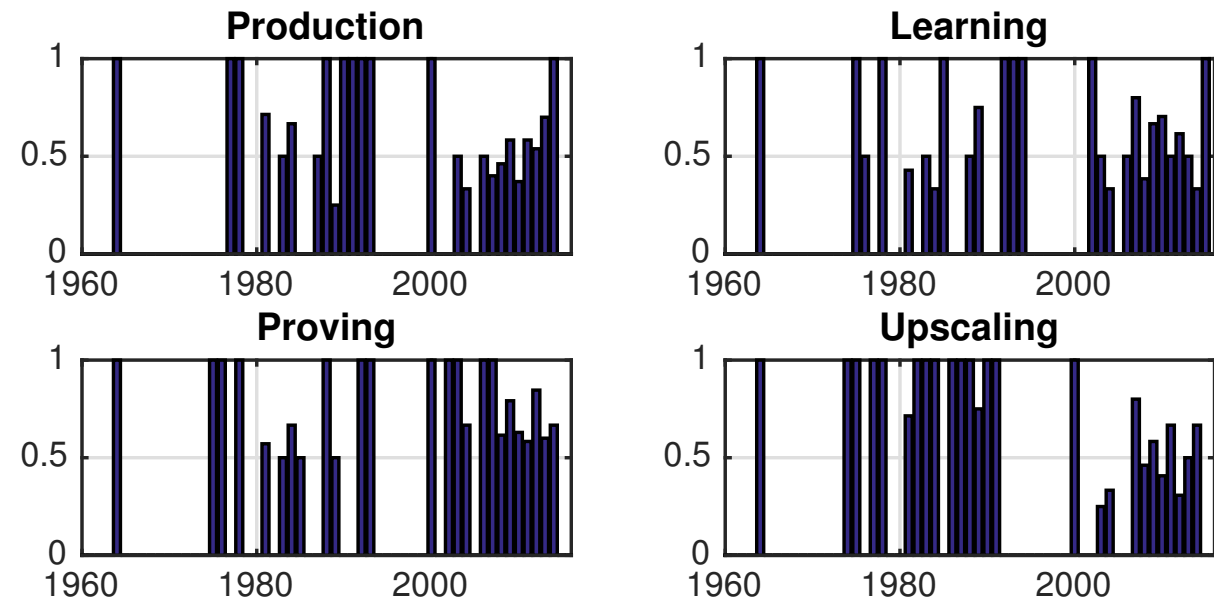

Figure 11: Motivations of demonstration projects included in analysis. Share of projects stating each motivation by year.

\section{A Supporting Information Document}

\section{A.1 Timing of demonstration projects}

We show averages across projects for indicators of timing in Table 2.

\section{A.2 Motivations for demonstration projects}

We show motivations over time in Figure 11. 


\section{A.3 Regression analysis of public funding share}

The correlations of the share of public funding with the starting year of the projects, the market variable as well as the sequence variable, let us to investigate this relationship further in a regression framework. As the dependent variable is a percentage, which also takes values of zero and one, we use a fractional logit estimation. The fractional logit estimation was developed by Papke and Wooldridge (1993) to take account of the bounded nature of percentage values while at the same time allowing for values at the boundaries. A logit transformation of the data is not adequate as this is not defined for values at the boundaries. These are however present in our data, as Figure 12 shows.

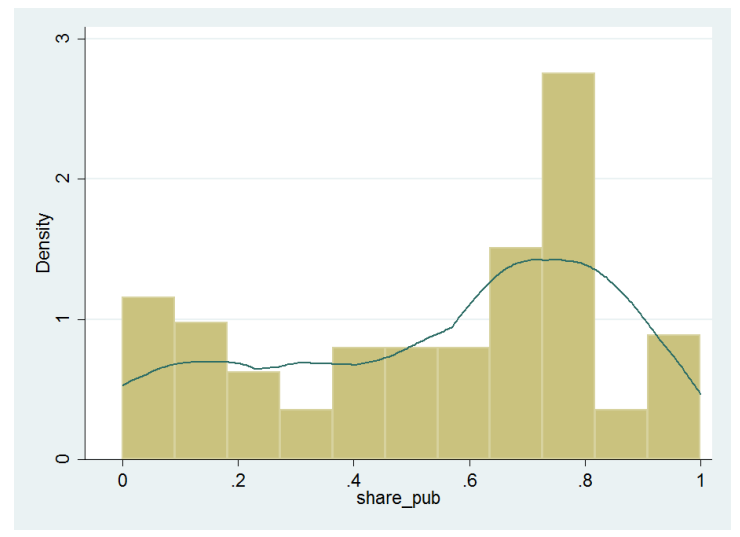

Figure 12: Histogram with kernel density of public share

Using the glm command in Stata (Baum, 2008), we specify dummies for each technologies and the budget in USD 2015 as our baseline explanatory variables. In subsequent estimations we add the starting year of the project, the starting year lagged by one year, a dummy variable indicating whether the project was cancelled, the market variable, and the sequence variable one by one to the baseline specification. We abstain from a joint estimation of these explanatory variables, as they show significant and high correlations amongst each other. The estimation results are shown in Table 3, with the baseline specification in column 2. We do not find any significant results, albeit the budget variable is slightly significant at the ten percent level in two out of six estimations with a negative sign. The dummy for the cancellation of projects is also found to be significantly negative. However, given these vague results, we are not able to draw conclusions from these estimations. 
Table 3: Fractional logit estimation for public funding share

\begin{tabular}{|c|c|c|c|c|c|c|c|}
\hline $\begin{array}{l}\text { Dep variable: } \\
\text { Public share }\end{array}$ & $\begin{array}{l}\text { (1) } \\
\text { share_pub }\end{array}$ & $\begin{array}{l}\text { (2) } \\
\text { share_pub }\end{array}$ & $\begin{array}{l}\text { (3) } \\
\text { share_pub }\end{array}$ & $\begin{array}{l}(4) \\
\text { share_pub }\end{array}$ & $\begin{array}{l}(5) \\
\text { share_pub }\end{array}$ & $\begin{array}{l}(6) \\
\text { share_pub }\end{array}$ & $\begin{array}{l}(7) \\
\text { share_pub }\end{array}$ \\
\hline D STE & $\begin{array}{l}-0.21 \\
(-0.77)\end{array}$ & $\begin{array}{l}-0.32 \\
(-1.17)\end{array}$ & $\begin{array}{l}-110.1 \\
(-86.22)\end{array}$ & $\begin{array}{l}-101.1 \\
(-86.17)\end{array}$ & $\begin{array}{l}-0.32 \\
(-1.17)\end{array}$ & $\begin{array}{l}-1.12 \\
(-1.48)\end{array}$ & $\begin{array}{l}-0.35 \\
(-1.17)\end{array}$ \\
\hline D Wind power & $\begin{array}{l}-0.11 \\
(-0.56)\end{array}$ & $\begin{array}{l}0.64 \\
(-0.59)\end{array}$ & $\begin{array}{l}-108.5 \\
(-85.67)\end{array}$ & $\begin{array}{l}-108.4 \\
(-85.62) \\
\end{array}$ & $\begin{array}{l}1.004 \\
(-0.7)\end{array}$ & $\begin{array}{l}-0.1 \\
(-0.83)\end{array}$ & $\begin{array}{l}0.61 \\
(-0.6)\end{array}$ \\
\hline D CCS energy & $\begin{array}{l}-0.27 \\
(-0.27)\end{array}$ & $\begin{array}{l}-0.15 \\
(-0.28)\end{array}$ & $\begin{array}{l}-110.6 \\
(-86.63)\end{array}$ & $\begin{array}{l}-110.5 \\
(-86.59)\end{array}$ & $\begin{array}{l}0.15 \\
(-0.32)\end{array}$ & $\begin{array}{l}-0.65 \\
(-0.57)\end{array}$ & $\begin{array}{l}-0.26 \\
(-0.31)\end{array}$ \\
\hline D CCS industry & $\begin{array}{l}0.43^{* * *} \\
(-0.16)\end{array}$ & $\begin{array}{l}0.46^{* * *} \\
(-0.17)\end{array}$ & $\begin{array}{l}-109.9 \\
(-86.62)\end{array}$ & $\begin{array}{l}-109.9 \\
(-86.57)\end{array}$ & $\begin{array}{l}0.6^{* * *} \\
(-0.16)\end{array}$ & $\begin{array}{l}0.12 \\
(-0.5)\end{array}$ & $\begin{array}{l}0.22 \\
(-0.38)\end{array}$ \\
\hline D Steel & $\begin{array}{l}0.84 \\
(-0.59)\end{array}$ & $\begin{array}{l}0.74 \\
(-0.66)\end{array}$ & $\begin{array}{l}-109.2 \\
(-86.26)\end{array}$ & $\begin{array}{l}-109.1 \\
(-86.21)\end{array}$ & $\begin{array}{l}0.75 \\
(-0.67)\end{array}$ & $\begin{array}{l}-0.066 \\
(-1.02)\end{array}$ & $\begin{array}{l}0.69 \\
(-0.66)\end{array}$ \\
\hline D Cement & $\begin{array}{l}0.21 \\
(-0.74)\end{array}$ & $\begin{array}{l}0.23 \\
(-0.75)\end{array}$ & $\begin{array}{l}-110.3 \\
(-86.71)\end{array}$ & $\begin{array}{l}-110.3 \\
(-86.67)\end{array}$ & $\begin{array}{l}0.23 \\
(-0.75)\end{array}$ & $\begin{array}{l}-0.72 \\
(-1.22)\end{array}$ & $\begin{array}{l}0.21 \\
(-0.76)\end{array}$ \\
\hline D Synfuels & $\begin{array}{l}-0.47 \\
(-0.71)\end{array}$ & $\begin{array}{l}-0.19 \\
(-0.79)\end{array}$ & $\begin{array}{l}-108.8 \\
(-85.15)\end{array}$ & $\begin{array}{l}-108.7 \\
(-85.11)\end{array}$ & $\begin{array}{l}0.21 \\
(-0.74)\end{array}$ & $\begin{array}{l}-0.91 \\
(-1.45)\end{array}$ & $\begin{array}{l}-0.23 \\
(-0.78)\end{array}$ \\
\hline D Biofuels & $\begin{array}{l}0.14 \\
(-0.2)\end{array}$ & $\begin{array}{l}0.19 \\
(-0.22)\end{array}$ & $\begin{array}{l}-110.2 \\
(-86.7)\end{array}$ & $\begin{array}{l}-110.2 \\
(-86.65)\end{array}$ & $\begin{array}{l}0.29 \\
(-0.24)\end{array}$ & $\begin{array}{l}-0.75 \\
(-1.01)\end{array}$ & $\begin{array}{l}0.065 \\
(-0.28)\end{array}$ \\
\hline Budget & & $\begin{array}{l}-0.000046 \\
(0)\end{array}$ & $\begin{array}{l}-0.000047 \\
(0)\end{array}$ & $\begin{array}{l}-0.000047 \\
(0)\end{array}$ & $\begin{array}{l}-0.000048^{*} \\
(0)\end{array}$ & $\begin{array}{l}-0.00005^{*} \\
(0)\end{array}$ & $\begin{array}{l}-0.00004 \\
(0)\end{array}$ \\
\hline Year begin & & & $\begin{array}{l}0.055 \\
(-0.04)\end{array}$ & & & & \\
\hline L1 Year begin & & & & $\begin{array}{l}0.055 \\
-0.04\end{array}$ & & & \\
\hline D Cancelled & & & & & $\begin{array}{l}-0.54^{* *} \\
(-0.27)\end{array}$ & & \\
\hline Market & & & & & & $\begin{array}{l}0.008 \\
(-0.01)\end{array}$ & \\
\hline Sequence & & & & & & & $\begin{array}{l}0.01 \\
(-0.01)\end{array}$ \\
\hline $\mathrm{N}$ & 126 & 107 & 107 & 107 & 107 & 103 & 107 \\
\hline
\end{tabular}

Note: Standard errors in parentheses. Significance levels ${ }^{*} \mathrm{p}<0.10,{ }^{* *} \mathrm{p}<0.05, * * *$ $\mathrm{p}<0.01$

\section{A.4 Project Characteristics}

We include basic characteristics in tables of demonstration projects for electricity sector technologies: solar thermal electricity (Table 13), nuclear power (Tables 14, 15, 16, and 17), wind power (Table 18), and CCS for power plants (Table 19). Industrial sectors are shown for industrial CCS (Table 20), steel (Table 21), and cement (Table 22). Liquid fuels are shown for synthetic fuels (Tables 23) and cellulosic biofuels (Tables 24 and 25). 


\begin{tabular}{|c|c|c|c|c|c|c|c|c|c|c|}
\hline $\begin{array}{l}\text { Solar Thermal Electricity - } \\
\text { Project cases }\end{array}$ & $\begin{array}{l}\text { Begin } \\
\text { year }\end{array}$ & On line & $\begin{array}{l}\text { End } \\
\text { year }\end{array}$ & $\begin{array}{l}\text { Budget in } \\
\text { million USD }\end{array}$ & Country & $\begin{array}{l}\text { Availability } \\
\text { Motivation } \\
\text { data }\end{array}$ & $\begin{array}{l}\text { Public financial } \\
\text { contribution }\end{array}$ & $\begin{array}{l}\text { Output per } \\
\text { year }\end{array}$ & $\begin{array}{l}\text { Output } \\
\text { unit }\end{array}$ & \\
\hline SEGS & 1984 & & 1989 & 2371.0 & USA & 1 & $0 \%$ & 80 & & MW \\
\hline LaFlorida & 2008 & 2010 & 2020 & & Spain & 1 & & 50 & & MW \\
\hline KIMBERLINA & 2008 & 2008 & 2020 & & USA & 1 & & 5 & & MW \\
\hline JÜLICH & 2008 & & 2020 & & Germany & 0 & & 1.5 & & MW \\
\hline ERRADO & 2008 & 2009 & 2020 & & Spain & 0 & & 1.4 & & MW \\
\hline SOLABEN & 2009 & 2012 & 2020 & 1067.6 & Spain & 1 & & 200 & & MW \\
\hline DAHAN & 2009 & 2012 & 2020 & 5.2 & China & 0 & & 1 & & MW \\
\hline MARICOPA & 2009 & 2010 & 2020 & & USA & 0 & & 1.5 & & MW \\
\hline IVANPAH & 2010 & 2014 & 2020 & 2386.0 & USA & 1 & $79 \%$ & 392 & & MW \\
\hline SOLANA & 2010 & 2013 & 2020 & 2169.1 & USA & 1 & & 250 & & MW \\
\hline COLOR & 2010 & 2010 & 2013 & 4.9 & USA & 1 & & 2 & & MW \\
\hline CARGELLIGO & 2010 & 2011 & 2020 & & Australia & 0 & $56 \%$ & 3 & & MW \\
\hline UATECH & 2011 & 2012 & 2020 & 34.0 & USA & 1 & & 5 & & MW \\
\hline INDIA & 2011 & 2012 & 2020 & & India & 0 & & 1 & & MW \\
\hline GREENWAY & 2011 & 2012 & 2020 & 53.1 & Turkey & 0 & & 1.4 & & MW \\
\hline AUGUSTIN & 2011 & 2012 & 2020 & & France & 0 & & 0.25 & & MW \\
\hline NOOR & 2012 & 2016 & 2020 & 1940.7 & Morocco & 1 & & 580 & & MW \\
\hline ASE & 2012 & 2013 & 2020 & & Italy & 0 & & 0.35 & & MW \\
\hline ALBA & 2013 & & 2020 & & France & 0 & & 12 & & MW \\
\hline ISSC & 2013 & 2014 & 2020 & 9.2 & USA & 0 & & 1 & & MW \\
\hline RENDE & 2013 & 2014 & 2020 & & Italy & 0 & & 1 & & MW \\
\hline ECARE & 2013 & 2014 & 2020 & & Morocco & 0 & & 1 & & MW \\
\hline JEMALONG & 2014 & 2017 & 2020 & 9.2 & Australia & 0 & & 1.1 & & MW \\
\hline IRESEN & 2015 & 2017 & 2020 & 6.2 & Morocco & 1 & & 1 & & MW \\
\hline
\end{tabular}

Figure 13: Demonstration projects: 1. Solar Thermal Electricity 


\begin{tabular}{|c|c|c|c|c|c|c|c|c|c|}
\hline $\begin{array}{l}\text { Nuclear Power - } \\
\text { Project cases }\end{array}$ & $\begin{array}{l}\text { Begin } \\
\text { year }\end{array}$ & On line & $\begin{array}{l}\text { End } \\
\text { year }\end{array}$ & $\begin{array}{l}\text { Budget in } \\
\text { million USD }\end{array}$ & Country & $\begin{array}{l}\text { Availability } \\
\text { Motivation } \\
\end{array}$ & $\begin{array}{l}\text { Public financial } \\
\text { contribution }\end{array}$ & $\begin{array}{l}\begin{array}{l}\text { Output per } \\
\text { year }\end{array} \\
\end{array}$ & $\begin{array}{l}\text { Output } \\
\text { unit }\end{array}$ \\
\hline APS-1 OBNINSK & 1951 & 1955 & 2002 & & RU & 0 & & 5 & MW \\
\hline CALDER HALL- 1 & 1954 & 1957 & 2003 & & GB & 0 & & 49 & MW \\
\hline CALDER HALL- 2 & 1954 & 1957 & 2003 & & GB & 0 & & 49 & MW \\
\hline SHIPPINGPORT & 1954 & 1958 & 1983 & & US & 0 & & 60 & MW \\
\hline DOUNREAY DFR & 1955 & 1963 & 1977 & & GB & 0 & & 11 & MW \\
\hline G-2 (MARCOULE) & 1955 & 1959 & 1980 & & $F R$ & 0 & & 39 & MW \\
\hline CALDER HALL-3 & 1956 & 1958 & 2003 & & GB & 0 & & 49 & MW \\
\hline CALDER HALL-4 & 1956 & 1959 & 2003 & & GB & 0 & & 49 & MW \\
\hline CHAPELCROSS-1 & 1956 & 1959 & 2005 & & GB & 0 & & 48 & MW \\
\hline CHAPELCROSS- 2 & 1956 & 1960 & 2005 & & GB & 0 & & 48 & MW \\
\hline CHAPELCROSS-3 & 1956 & 1960 & 2005 & & GB & 0 & & 48 & MW \\
\hline CHAPELCROSS-4 & 1956 & 1960 & 2005 & & GB & 0 & & 48 & MW \\
\hline GE VALLECITOS & 1956 & 1958 & 1964 & & US & 0 & & 24 & MW \\
\hline G-3 (MARCOULE) & 1956 & 1960 & 1985 & & $F R$ & 0 & & 40 & MW \\
\hline DRESDEN-1 & 1956 & 1961 & 1979 & & US & 0 & & 197 & MW \\
\hline INDIAN POINT-1 & 1956 & 1963 & 1975 & & US & 0 & & 257 & MW \\
\hline FERMI-1 & 1957 & & 1973 & & US & 0 & & 61 & MW \\
\hline BERKELEY-1 & 1957 & 1963 & 1989 & & GB & 0 & & 138 & Mw \\
\hline BERKELEY-2 & 1957 & 1963 & 1989 & & GB & 0 & & 138 & MW \\
\hline BRADWELL-1 & 1957 & 1963 & 2002 & & GB & 0 & & 123 & MW \\
\hline BRADWELL-2 & 1957 & 1963 & 2002 & & GB & 0 & & 123 & MW \\
\hline CHINON A-1 & 1957 & 1964 & 1973 & & $F R$ & 0 & & 70 & MW \\
\hline NOVOVORONEZH-1 & 1958 & 1965 & 1988 & & RU & 0 & & 197 & MW \\
\hline HUNTERSTON A-1 & 1958 & 1964 & 1990 & & GB & 0 & & 150 & MW \\
\hline HUNTERSTON A-2 & 1958 & 1965 & 1990 & & GB & 0 & & 150 & MW \\
\hline HINKLEY POINT A-1 & 1958 & 1965 & 2000 & & GB & 0 & & 235 & MW \\
\hline HINKLEY POINT A-2 & 1958 & 1965 & 2000 & & GB & 0 & & 235 & MW \\
\hline BR-3 & 1958 & 1963 & 1988 & & $B E$ & 0 & & 10 & MW \\
\hline YANKEE NPS & 1958 & 1962 & 1992 & & US & 0 & & 167 & MW \\
\hline AGESTA & 1958 & 1964 & 1975 & & SE & 0 & & 10 & MW \\
\hline ROLPHTON NPD & 1958 & 1963 & 1988 & & $\mathrm{CA}$ & 0 & & 22 & MW \\
\hline BELOYARSK-1 & 1959 & 1964 & 1983 & & $\mathrm{RU}$ & 0 & & 102 & MW \\
\hline VAK KAHL & 1959 & 1962 & 1986 & & DE & 0 & & 15 & MW \\
\hline BOHUNICE A1 & 1959 & 1973 & 1977 & & SK & 0 & & 93 & MW \\
\hline LATINA & 1959 & 1964 & 1988 & & IT & 0 & & 153 & MW \\
\hline WINDSCALE AGR & 1959 & 1963 & 1981 & & GB & 0 & & 24 & MW \\
\hline ELK RIVER & 1959 & 1965 & 1968 & & US & 0 & & 22 & MW \\
\hline PATHFINDER & 1959 & & 1968 & & US & 0 & & 59 & MW \\
\hline HALLAM & 1959 & 1964 & 1965 & & US & 0 & & 75 & MW \\
\hline TRAWSFYNYDD-1 & 1960 & 1965 & 1991 & & GB & 0 & & 195 & MW \\
\hline TRAWSFYNYDD-2 & 1960 & 1965 & 1991 & & GB & 0 & & 195 & MW \\
\hline CHINON A-2 & 1960 & 1965 & 1986 & & $F R$ & 0 & & 180 & MW \\
\hline GARIGLIANO & 1960 & 1965 & 1982 & & IT & 0 & & 150 & MW \\
\hline BONUS & 1960 & 1966 & 1969 & & US & 0 & & 17 & MW \\
\hline CVTR & 1960 & & 1967 & & US & 0 & & 17 & MW \\
\hline RHEINSBERG & 1960 & 1967 & 1991 & & DE & 0 & & 62 & MW \\
\hline SAXTON & 1960 & 1967 & 1972 & & US & 0 & & 3 & MW \\
\hline PIQUA & 1960 & 1964 & 1966 & & US & 0 & & 12 & MW \\
\hline DOUGLAS POINT & 1960 & 1969 & 1984 & & $\mathrm{CA}$ & 0 & & 206 & Mw \\
\hline BIG ROCK POINT & 1960 & 1963 & 1998 & & US & 0 & & 67 & MW \\
\hline DUNGENESS A-1 & 1961 & 1966 & 2007 & & GB & 0 & & 225 & MW \\
\hline DUNGENESS A-2 & 1961 & 1966 & 2007 & & GB & 0 & & 225 & MW \\
\hline HUMBOLDT BAY & 1961 & 1964 & 1977 & & US & 0 & & 63 & MW \\
\hline JPDR & 1961 & 1965 & 1976 & & JP & 0 & & 12 & MW \\
\hline TOKAI-1 & 1961 & 1967 & 1998 & & JP & 0 & & 137 & Mw \\
\hline CHINON A-3 & 1961 & 1967 & 1991 & & $F R$ & 0 & & 360 & MW \\
\hline SIZEWELL A-1 & 1961 & 1966 & 2007 & & GB & 0 & & 210 & MW \\
\hline SIZEWELL A-2 & 1961 & 1967 & 2007 & & GB & 0 & & 210 & MW \\
\hline ENRICO FERMI & 1962 & 1965 & 1991 & & IT & 0 & & 260 & MW \\
\hline AVR JUELICH & 1962 & 1969 & 1989 & & $\mathrm{DE}$ & 0 & & 13 & MW \\
\hline MZFR & 1962 & 1967 & 1984 & & $\mathrm{DE}$ & 0 & & 52 & MW \\
\hline
\end{tabular}

Figure 14: Demonstration projects: 2. Nuclear power, part 1. 


\begin{tabular}{|c|c|c|c|c|c|c|c|c|c|}
\hline $\begin{array}{l}\text { Nuclear Power - } \\
\text { Project cases }\end{array}$ & $\begin{array}{l}\text { Begin } \\
\text { year }\end{array}$ & On line & $\begin{array}{l}\text { End } \\
\text { year }\end{array}$ & $\begin{array}{l}\text { Budget in } \\
\text { million USD }\end{array}$ & Country & $\begin{array}{l}\text { Availability } \\
\text { Motivation } \\
\text { data }\end{array}$ & $\begin{array}{l}\text { Public financial } \\
\text { contribution }\end{array}$ & $\begin{array}{l}\text { Output per } \\
\text { year }\end{array}$ & $\begin{array}{l}\text { Output } \\
\text { unit }\end{array}$ \\
\hline BELOYARSK-2 & 1962 & 1970 & 1990 & & RU & 0 & & 146 & MW \\
\hline CHOOZ-A & 1962 & 1967 & 1992 & & $F R$ & 0 & & 305 & MW \\
\hline PEACH BOTTOM-1 & 1962 & 1968 & 1975 & & US & 0 & & 40 & MW \\
\hline LUCENS & 1962 & & 1969 & & $\mathrm{CH}$ & 0 & & 6 & MW \\
\hline OLDBURY A-1 & 1962 & 1968 & 2012 & & GB & 0 & & 217 & MW \\
\hline OLDBURY A-2 & 1962 & 1969 & 2012 & & GB & 0 & & 217 & MW \\
\hline EL-4 & 1963 & 1969 & 1986 & & $F R$ & 0 & & 70 & MW \\
\hline GUNDREMMINGEN-A & 1963 & 1967 & 1977 & & DE & 0 & & 237 & MW \\
\hline LACROSSE & 1963 & 1970 & 1987 & & US & 0 & & 48 & MW \\
\hline WINFRITH SGHWR & 1963 & 1968 & 1991 & & GB & 0 & & 92 & MW \\
\hline ST. LAURENT A-1 & 1964 & 1970 & 1990 & & $F R$ & 0 & & 390 & MW \\
\hline JOSE CABRERA-1 & 1965 & 1970 & 2006 & & ES & 0 & & 141 & MW \\
\hline LINGEN & 1965 & 1969 & 1977 & & DE & 0 & & 183 & MW \\
\hline AKTAU & 1965 & 1974 & 1999 & & $K Z$ & 0 & & 52 & MW \\
\hline TARAPUR-1 & 1965 & 1970 & 2020 & & INDIA & 0 & & 150 & MW \\
\hline TARAPUR-2 & 1965 & 1970 & 2020 & & INDIA & 0 & & 150 & MW \\
\hline HDR GROSSWELZHEIM & 1965 & 1971 & 1971 & & $\mathrm{DE}$ & 0 & & 25 & MW \\
\hline OBRIGHEIM & 1965 & 1969 & 2005 & & DE & 0 & & 340 & MW \\
\hline DODEWAARD & 1965 & 1969 & 1997 & & NL & 0 & & 55 & MW \\
\hline RAJASTHAN-1 & 1966 & 1974 & 2020 & & INDIA & 0 & & 90 & MW \\
\hline BEZNAU-1 & 1966 & 1970 & 2020 & & SWITZERLANI & 0 & & 365 & MW \\
\hline DUNGENESS B-1 & 1966 & 1985 & 2020 & & UK & 0 & & 525 & MW \\
\hline DOUNREAY PFR & 1966 & 1977 & 1994 & & GB & 0 & & 234 & MW \\
\hline NIEDERAICHBACH & 1967 & 1973 & 1975 & & $\mathrm{DE}$ & 0 & & 100 & MW \\
\hline PICKERING-1 & 1967 & 1972 & 2020 & & CANADA & 0 & & 515 & MW \\
\hline OSKARSHAMN-1 & 1967 & 1972 & 2020 & & SWEDEN & 0 & & 473 & MW \\
\hline KANUPP & 1967 & 1973 & 2020 & & PAKISTAN & 0 & & 90 & MW \\
\hline GENTILLY-1 & 1967 & 1972 & 1978 & & $\mathrm{CA}$ & 0 & & 250 & MW \\
\hline PICKERING-2 & 1967 & 1972 & 2007 & & $\mathrm{CA}$ & 0 & & 515 & MW \\
\hline MUEHLEBERG & 1967 & 1973 & 2020 & & SWITZERLANI & 0 & & 373 & MW \\
\hline PALISADES & 1967 & 1972 & 2020 & & USA & 0 & & 805 & MW \\
\hline FUKUSHIMA-DAIICHI-1 & 1968 & 1971 & 2011 & & $J P$ & 0 & & 439 & MW \\
\hline NOVOVORONEZH-3 & 1968 & 1973 & 2020 & & RUSSIA & 0 & & 385 & MW \\
\hline HINKLEY POINT B-1 & 1968 & 1979 & 2020 & & UK & 0 & & 480 & MW \\
\hline OCONEE-1 & 1968 & 1974 & 2020 & & USA & 0 & & 846 & MW \\
\hline STADE & 1968 & 1972 & 2004 & & DE & 0 & & 640 & MW \\
\hline RAJASTHAN-2 & 1968 & 1981 & 2020 & & INDIA & 0 & & 187 & MW \\
\hline MIHAMA-2 & 1968 & 1973 & 2015 & & JP & 0 & & 470 & MW \\
\hline VANDELLOS-1 & 1969 & 1973 & 1991 & & ES & 0 & & 480 & MW \\
\hline ATUCHA-1 & 1969 & 1975 & 2020 & & ARGENTINA & 0 & & 340 & MW \\
\hline FORT ST. VRAIN & 1969 & 1980 & 1990 & & US & 0 & & 330 & MW \\
\hline MAINE YANKEE & 1969 & 1973 & 1998 & & US & 0 & & 860 & MW \\
\hline HARTLEPOOL A-1 & 1969 & 1989 & 2020 & & UK & 0 & & 595 & MW \\
\hline PHENIX & 1969 & 1975 & 2010 & & $F R$ & 0 & & 130 & MW \\
\hline BELOYARSK-3 & 1969 & 1982 & 2020 & & RUSSIA & 0 & & 560 & MW \\
\hline RANCHO SECO-1 & 1969 & 1975 & 1990 & & US & 0 & & 873 & MW \\
\hline FUKUSHIMA-DAIICHI-2 & 1970 & 1975 & 2011 & & $J P$ & 0 & & 760 & MW \\
\hline ARMENIAN-1 & 1970 & 1978 & 1989 & & AM & 0 & & 376 & MW \\
\hline DOEL-1 & 1970 & 1975 & 2020 & & BELGIUM & 0 & & 433 & MW \\
\hline BORSSELE & 1970 & 1974 & 2020 & & NETHERLAND & 0 & & 482 & MW \\
\hline THREE MILE ISLAND-2 & 1970 & 1979 & 1979 & & US & 0 & & 880 & MW \\
\hline CAORSO & 1970 & 1982 & 1991 & & IT & 0 & & 860 & MW \\
\hline BILIBINO-1 & 1970 & 1974 & 2020 & & RUSSIA & 0 & & 11 & MW \\
\hline BILIBINO-2 & 1970 & 1975 & 2020 & & RUSSIA & 0 & & 11 & MW \\
\hline BILIBINO-3 & 1970 & 1976 & 2020 & & RUSSIA & 0 & & 11 & MW \\
\hline BILIBINO-4 & 1970 & 1977 & 2020 & & RUSSIA & 0 & & 11 & MW \\
\hline CHERNOBYL-1 & 1970 & 1978 & 1997 & & UA & 0 & & 740 & MW \\
\hline BRUNSBUETTEL & 1970 & 1977 & 2012 & & DE & 0 & & 771 & MW \\
\hline KOZLODUY-1 & 1970 & 1975 & 2003 & & BG & 0 & & 408 & MW \\
\hline TAKAHAMA-1 & 1970 & 1975 & 2020 & & JAPAN & 0 & & 780 & MW \\
\hline TIHANGE-1 & 1971 & 1976 & 2020 & & BELGIUM & 0 & & 962 & MW \\
\hline
\end{tabular}

Figure 15: Demonstration projects: 2. Nuclear power, part 2. 


\begin{tabular}{|c|c|c|c|c|c|c|c|c|c|c|}
\hline $\begin{array}{l}\text { Nuclear Power - } \\
\text { Project cases }\end{array}$ & $\begin{array}{l}\text { Begin } \\
\text { year }\end{array}$ & On line & $\begin{array}{l}\text { End } \\
\text { year }\end{array}$ & $\begin{array}{l}\text { Budget in } \\
\text { million USD }\end{array}$ & Country & $\begin{array}{l}\text { Availability } \\
\text { Motivation } \\
\text { data } \\
\end{array}$ & $\begin{array}{l}\text { Public financial } \\
\text { contribution }\end{array}$ & $\begin{array}{l}\text { Output per } \\
\text { year }\end{array}$ & $\begin{array}{l}\text { Output } \\
\text { unit }\end{array}$ & \\
\hline SHIMANE-1 & 1971 & 1974 & 2015 & & JP & 0 & & 439 & & $\mathrm{MW}$ \\
\hline FUKUSHIMA-DAIICHI-3 & 1971 & 1976 & 2011 & & JP & 0 & & 760 & & MW \\
\hline MADRAS-1 & 1971 & 1984 & 2020 & & INDIA & 0 & & 205 & & MW \\
\hline BARSEBACK-1 & 1971 & 1976 & 2000 & & SE & 0 & & 600 & & MW \\
\hline TAKAHAMA-2 & 1971 & 1976 & 2020 & & JAPAN & 0 & & 780 & & MW \\
\hline THTR-300 & 1971 & 1988 & 1989 & & DE & 0 & & 296 & & MW \\
\hline LOVIISA-1 & 1971 & 1977 & 2020 & & FINLAND & 0 & & 496 & & MW \\
\hline FESSENHEIM-1 & 1972 & 1978 & 2020 & & FRANCE & 0 & & 880 & & MW \\
\hline GREIFSWALD-3 & 1972 & 1978 & 1990 & & DE & 0 & & 408 & & MW \\
\hline GREIFSWALD-4 & 1972 & 1980 & 1991 & & DE & 0 & & 408 & & MW \\
\hline FUGEN ATR & 1972 & 1979 & 2003 & & JP & 0 & & 148 & & MW \\
\hline MADRAS-2 & 1973 & 1986 & 2020 & & INDIA & 0 & & 205 & & MW \\
\hline SHOREHAM & 1973 & & 1989 & & US & 0 & & 820 & & MW \\
\hline BARSEBACK-2 & 1973 & 1978 & 2005 & & SE & 0 & & 600 & & MW \\
\hline CHERNOBYL-2 & 1973 & 1979 & 1992 & & UA & 0 & & 925 & & MW \\
\hline ROVNO-1 & 1974 & 1982 & 2020 & & UKRAINE & 0 & & 381 & & MW \\
\hline WATTS BAR-2 & 1974 & & 2020 & & USA & 0 & & 1165 & & MW \\
\hline GOESGEN & 1974 & 1980 & 2020 & & SWITZERLANI & 0 & & 1010 & & MW \\
\hline OLKILUOTO-1 & 1974 & 1980 & 2020 & & FINLAND & 0 & & 880 & & MW \\
\hline KNK ॥ & 1975 & 1979 & 1992 & & $\mathrm{DE}$ & 0 & & 17 & & MW \\
\hline MUELHEIM-KAERLICH & 1975 & 1988 & 1989 & & $\mathrm{DE}$ & 0 & & 1219 & & MW \\
\hline DOEL-3 & 1975 & 1983 & 2020 & & BELGIUM & 0 & & 1006 & & Mw \\
\hline BUSHEHR-1 & 1975 & 2014 & 2020 & & IRAN & 0 & & 915 & & Mw \\
\hline ARMENIAN-2 & 1976 & 1980 & 2020 & & ARMENIA & 0 & & 375 & & MW \\
\hline FUKUSHIMA-DAINI-1 & 1976 & 1982 & 2020 & & JAPAN & 0 & & 1067 & & MW \\
\hline GUNDREMMINGEN-B & 1977 & 1985 & 2020 & & GERMANY & 0 & & 1284 & & MW \\
\hline SOUTH UKRAINE-1 & 1977 & 1984 & 2020 & & UKRAINE & 0 & & 950 & & MW \\
\hline SUPER-PHENIX & 1977 & 1987 & 1999 & & $F R$ & 0 & & 1200 & & MW \\
\hline GREIFSWALD-5 & 1977 & 1990 & 1990 & & DE & 0 & & 408 & & MW \\
\hline NARORA-1 & 1977 & 1991 & 2020 & & INDIA & 0 & & 202 & & MW \\
\hline BOHUNICE-3 & 1977 & 1985 & 2020 & & SLOVAKIA & 0 & & 471 & & MW \\
\hline IGNALINA-1 & 1977 & 1985 & 2005 & & LT & 0 & & 1185 & & MW \\
\hline NARORA-2 & 1978 & 1993 & 2020 & & INDIA & 0 & & 202 & & MW \\
\hline CHERNOBYL-4 & 1979 & 1984 & 1986 & & UA & 0 & & 925 & & MW \\
\hline FUKUSHIMA-DAINI-2 & 1979 & 1984 & 2020 & & JAPAN & 0 & & 1067 & & MW \\
\hline TORNESS-1 & 1981 & 1988 & 2020 & & UK & 0 & & 590 & & MW \\
\hline KAKRAPAR-1 & 1985 & 1993 & 2020 & & INDIA & 0 & & 202 & & MW \\
\hline QINSHAN-1 & 1985 & 1994 & 2020 & & CHINA & 0 & & 298 & & MW \\
\hline KAKRAPAR- 2 & 1985 & 1996 & 2020 & & INDIA & 0 & & 202 & & MW \\
\hline KHMELNITSKI-3 & 1986 & & 2020 & & UKRAINE & 0 & & 950 & & MW \\
\hline MOCHOVCE-3 & 1987 & & 2020 & & SLOVAKIA & 0 & & 440 & & MW \\
\hline SIZEWELL B & 1989 & 1996 & 2020 & & UK & 0 & & 1198 & & MW \\
\hline KAIGA-1 & 1990 & 2001 & 2020 & & INDIA & 0 & & 202 & & MW \\
\hline KAIGA-2 & 1990 & 2000 & 2020 & & INDIA & 0 & & 202 & & MW \\
\hline HANBIT-3 & 1990 & 1995 & 2020 & & KOREA RO & 0 & & 994 & & MW \\
\hline RAJASTHAN-3 & 1990 & 2001 & 2020 & & INDIA & 0 & & 202 & & MW \\
\hline RAJASTHAN-4 & 1991 & 2001 & 2020 & & INDIA & 0 & & 202 & & MW \\
\hline WOLSONG-2 & 1993 & 1998 & 2020 & & KOREA RO & 0 & & 652 & & MW \\
\hline HANUL-3 & 1994 & 1999 & 2020 & & KOREA RO & 0 & & 997 & & MW \\
\hline LUNGMEN 1 & 1999 & & 2020 & & TAIWAN CN & 0 & & 1300 & & MW \\
\hline TIANWAN-1 & 2000 & 2007 & 2020 & & CHINA & 0 & & 990 & & MW \\
\hline CEFR & 2000 & 2001 & 2020 & & CHINA & 0 & & 20 & & MW \\
\hline KAIGA-3 & 2002 & 2007 & 2020 & & INDIA & 0 & & 202 & & MW \\
\hline KUDANKULAM-1 & 2002 & 2015 & 2020 & & INDIA & 0 & & 917 & & MW \\
\hline KAIGA-4 & 2002 & 2011 & 2020 & & INDIA & 0 & & 202 & & MW \\
\hline KUDANKULAM-2 & 2003 & & 2020 & & INDIA & 0 & & 917 & & MW \\
\hline RAJASTHAN-5 & 2003 & 2010 & 2020 & & INDIA & 0 & & 202 & & Mw \\
\hline RAJASTHAN- 6 & 2003 & 2010 & 2020 & & INDIA & 0 & & 202 & & MW \\
\hline PFBR & 2005 & & 2020 & & INDIA & 0 & & 470 & & MW \\
\hline OLKILUOTO-3 & 2006 & & 2020 & & FINLAND & 0 & & 1600 & & MW \\
\hline LNG AO-3 & 2006 & 2011 & 2020 & & CHINA & 0 & & 1007 & & MW \\
\hline
\end{tabular}

Figure 16: Demonstration projects: 2. Nuclear power, part 3. 


\begin{tabular}{|c|c|c|c|c|c|c|c|c|c|}
\hline $\begin{array}{l}\text { Nuclear Power - } \\
\text { Project cases }\end{array}$ & $\begin{array}{l}\text { Begin } \\
\text { year }\end{array}$ & On line & $\begin{array}{l}\text { End } \\
\text { year }\end{array}$ & $\begin{array}{l}\text { Budget in } \\
\text { million USD }\end{array}$ & Country & $\begin{array}{l}\text { Availability } \\
\text { Motivation } \\
\text { data }\end{array}$ & $\begin{array}{l}\text { Public financial } \\
\text { contribution }\end{array}$ & $\begin{array}{l}\text { Output per } \\
\text { year }\end{array}$ & $\begin{array}{l}\text { Output } \\
\text { unit }\end{array}$ \\
\hline AKADEMIK LOMONOSOV-: & 2007 & & 2020 & & RUSSIA & 0 & & 32 & MW \\
\hline AKADEMIK LOMONOSOV-: & 2007 & & 2020 & & RUSSIA & 0 & & 32 & MW \\
\hline SHIMANE-3 & 2008 & & 2020 & & JAPAN & 0 & & 1325 & MW \\
\hline SHIN-KORI-3 & 2009 & & 2020 & & KOREA RO & 0 & & 1400 & MW \\
\hline FUQING-1 & 2009 & 2015 & 2020 & & CHINA & 0 & & 1000 & MW \\
\hline NINGDE-2 & 2009 & 2014 & 2020 & & CHINA & 0 & & 1018 & MW \\
\hline YANGJIANG-1 & 2009 & 2014 & 2020 & & CHINA & 0 & & 1000 & MW \\
\hline SANMEN-1 & 2009 & & 2020 & & CHINA & 0 & & 1000 & MW \\
\hline HONGYANHE- 4 & 2010 & & 2020 & & CHINA & 0 & & 1000 & MW \\
\hline OHMA & 2010 & & 2020 & & JAPAN & 0 & & 1325 & MW \\
\hline ANGRA-3 & 2011 & & 2020 & & BRAZIL & 0 & & 1245 & MW \\
\hline NINGDE-4 & 2011 & & 2020 & & CHINA & 0 & & 1018 & MW \\
\hline KAKRAPAR-3 & 2011 & & 2020 & & INDIA & 0 & & 630 & Mw \\
\hline FUQING-3 & 2011 & & 2020 & & CHINA & 0 & & 1000 & MW \\
\hline CHASNUPP-3 & 2011 & & 2020 & & PAKISTAN & 0 & & 315 & MW \\
\hline BARAKAH-1 & 2013 & & 2020 & & UAE & 0 & & 1345 & MW \\
\hline SHIDAO BAY-1 & 2013 & & 2020 & & CHINA & 0 & & 200 & MW \\
\hline TIANWAN-3 & 2013 & & 2020 & & CHINA & 0 & & 990 & MW \\
\hline CAREM25 & 2014 & & 2020 & & ARGENTINA & 0 & & 25 & MW \\
\hline TIANWAN-5 & 2016 & & 2020 & & CHINA & 0 & & 1000 & MW \\
\hline
\end{tabular}

Figure 17: Demonstration projects: 2. Nuclear power, part 4.

\begin{tabular}{|c|c|c|c|c|c|c|c|c|c|}
\hline $\begin{array}{l}\text { Wind Power - } \\
\text { Project cases }\end{array}$ & $\begin{array}{l}\text { Begin } \\
\text { year }\end{array}$ & On line & $\begin{array}{l}\text { End } \\
\text { year }\end{array}$ & $\begin{array}{l}\text { Budget in } \\
\text { million USD }\end{array}$ & Country & $\begin{array}{l}\text { Availability } \\
\text { Motivation } \\
\text { data }\end{array}$ & $\begin{array}{l}\text { Public financial } \\
\text { contribution }\end{array}$ & $\begin{array}{l}\text { Output per } \\
\text { year }\end{array}$ & $\begin{array}{l}\text { Output } \\
\text { unit }\end{array}$ \\
\hline Smith-Putnam & 1940 & 1941 & 1945 & & USA & 1 & $0 \%$ & 1.25 & MW \\
\hline Mod-1 & 1974 & 1979 & 1983 & & USA & 1 & & 2 & MW \\
\hline Mod-0 & 1975 & 1975 & 1982 & & USA & 1 & & 0.1 & MW \\
\hline Tvind & 1976 & 1978 & 1993 & 3.3 & Denmark & 1 & & 2 & MW \\
\hline Mod-OA & 1976 & 1977 & 1984 & & USA & 1 & & 0.2 & MW \\
\hline Nibe-A & 1977 & 1979 & 1993 & 9.4 & Denmark & 1 & & 0.63 & MW \\
\hline Nibe-B & 1977 & 1980 & 1993 & 9.4 & Denmark & 1 & & 0.63 & MW \\
\hline Mod-2 & 1981 & 1982 & 1988 & 135.4 & USA & 1 & & 2.5 & MW \\
\hline Mod-2 PG\&E & 1981 & 1982 & 1988 & 18.0 & USA & 1 & & 2.5 & MW \\
\hline Growian & 1981 & 1983 & 1987 & 70.5 & Germany & 1 & $98 \%$ & 3 & MW \\
\hline WTS-4 & 1981 & 1982 & 1994 & & USA & 1 & & 4 & MW \\
\hline Maglarp WTS-3 & 1982 & 1983 & 1993 & & Sweden & 1 & & 3 & MW \\
\hline Näsudden & 1983 & 1983 & 1990 & & Sweden & 1 & & 2 & MW \\
\hline WKA 60 Growian II & 1984 & 1990 & 1995 & 30.5 & Germany & 1 & & 1.2 & MW \\
\hline Tjaereborg & 1986 & 1988 & 1993 & & Denmark & 1 & & 2 & MW \\
\hline WEG LS-1 & 1986 & 1987 & 1992 & & UK & 0 & & 3 & MW \\
\hline Mod-5B & 1987 & 1988 & 1996 & 100.7 & USA & 1 & & 3.2 & MW \\
\hline Éole & 1987 & 1988 & 1993 & 55.3 & Canada & 1 & & 3.6 & MW \\
\hline Aeolus II & 1988 & 1993 & 2008 & 25.2 & Germany & 1 & $48 \%$ & 3 & MW \\
\hline Howden & 1989 & 1990 & & . & UK & 1 & & 1 & MW \\
\hline AWEC 60 & 1989 & 1990 & & 2.7 & Spain & 1 & $50 \%$ & 1.2 & MW \\
\hline Gamma 60 & 1990 & 1992 & & & Italy & 1 & $40 \%$ & 1.5 & MW \\
\hline Näsuddden II & 1991 & 1993 & 2007 & 27.0 & Sweden & 1 & & 3 & MW \\
\hline
\end{tabular}

Figure 18: Demonstration projects: 3. Wind power. 


\begin{tabular}{|c|c|c|c|c|c|c|c|c|c|}
\hline $\begin{array}{l}\text { CCS for power plants - } \\
\text { Project cases }\end{array}$ & $\begin{array}{l}\text { Begin } \\
\text { year }\end{array}$ & On line & $\begin{array}{l}\text { End } \\
\text { year }\end{array}$ & $\begin{array}{l}\text { Budget in } \\
\text { million USD }\end{array}$ & Country & $\begin{array}{l}\text { Availability } \\
\text { Motivation } \\
\text { data }\end{array}$ & $\begin{array}{l}\text { Public financial } \\
\text { contribution }\end{array}$ & $\begin{array}{l}\text { Output per } \\
\text { year }\end{array}$ & $\begin{array}{l}\text { Output } \\
\text { unit }\end{array}$ \\
\hline Risavika & 2004 & & 2007 & 1.4 & Norway & 1 & & 70 & MW \\
\hline Halten & 2006 & & 2007 & 1.7 & Norway & 1 & & 860 & MW \\
\hline Goldenbergwerk & 2006 & & 2015 & 2905.1 & Germany & 1 & & 450 & MW \\
\hline Emirates & 2007 & & 2020 & & UAE & 0 & & 200 & MW \\
\hline Shengli & 2007 & 2010 & 2020 & & China & 1 & & & \\
\hline Taweelah & 2007 & 2018 & 2020 & 24812.3 & UAE & 1 & $68 \%$ & & \\
\hline Wallula & 2007 & & 2008 & 2481.2 & USA & 0 & & 700 & MW \\
\hline Appalachian & 2007 & 2012 & 2009 & 2515.1 & USA & 0 & & 629 & MW \\
\hline Kiwana & 2007 & 2014 & & 1887.5 & Australia & 0 & & 500 & MW \\
\hline Compostilla & 2008 & 2009 & 2012 & 343.1 & Spain & 1 & $80 \%$ & 320 & MW \\
\hline Jaenschwalde & 2008 & 2016 & 2011 & 2431.2 & Germany & 1 & $12 \%$ & 300 & MW \\
\hline TCEP & 2009 & 2019 & 2020 & 1896.0 & USA & 0 & $26 \%$ & 5 & MW \\
\hline GreenGen & 2009 & 2011 & 2020 & 1646.7 & China & 1 & $34 \%$ & 650 & MW \\
\hline Lianyungang & 2009 & 2015 & 2014 & & China & 1 & & 1200 & MW \\
\hline Wolverine & 2009 & & 2013 & & USA & 1 & & 300 & MW \\
\hline AntelopeValley & 2009 & & 2010 & 424.9 & USA & 1 & $26 \%$ & 120 & MW \\
\hline AEP.Mountaineer & 2009 & & 2011 & 109.8 & USA & 0 & $16 \%$ & 30 & MW \\
\hline FINNCAP & 2009 & 2015 & 2010 & & Finland & 1 & & 565 & MW \\
\hline Enel & 2009 & 2016 & 2016 & 3812.7 & Italy & 0 & $16 \%$ & 250 & MW \\
\hline BOUNDARY & 2010 & 2016 & 2020 & 1344.8 & Canada & 1 & $17 \%$ & 50 & MW \\
\hline KEMPER & 2010 & 2016 & 2020 & 7038.6 & USA & 1 & $27 \%$ & 250 & MW \\
\hline PetraNova & 2010 & 2016 & 2020 & 1084.5 & USA & 1 & $40 \%$ & 580 & MW \\
\hline TCM & 2010 & 2012 & 2020 & 1106.2 & Norway & 1 & $21 \%$ & 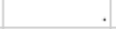 & \\
\hline Longyearbyien & 2010 & 2020 & 2020 & & Norway & 1 & & & \\
\hline Korea & 2010 & 2016 & 2020 & 161.4 & Korea & 1 & $100 \%$ & 500 & MW \\
\hline Westcarb & 2010 & 2011 & 2015 & 97.6 & USA & 1 & $72 \%$ & 50 & MW \\
\hline Taylorville & 2010 & 2015 & 2013 & 3795.9 & USA & 1 & $71 \%$ & 176 & MW \\
\hline Trailblazer & 2010 & & 2013 & 3253.6 & USA & 0 & $1 \%$ & 765 & MW \\
\hline BigBendStation & 2010 & & 2010 & & USA & 0 & & 1 & MW \\
\hline Pioneer & 2010 & 2015 & 2012 & 1361.1 & Canada & 0 & $62 \%$ & 450 & MW \\
\hline Longannet & 2010 & & 2011 & 1675.8 & Scotland & 0 & $100 \%$ & 330 & MW \\
\hline Boryeong & 2010 & 2013 & 2020 & 45.6 & South Korea & 1 & $58 \%$ & 10 & MW \\
\hline Bow & 2011 & 2014 & 2020 & 3.1 & Canada & 1 & & 1000 & MW \\
\hline Daqing & 2011 & 2015 & 2020 & & China & 1 & & 1350 & MW \\
\hline Dongguan & 2011 & 2015 & 2020 & & China & 1 & & 800 & MW \\
\hline ROAD & 2012 & 2019 & 2020 & 1252.0 & Netherlands & 1 & $18 \%$ & 250 & MW \\
\hline WHITE & 2012 & 2020 & 2020 & & UK & 1 & & 448 & MW \\
\hline PETERHEAD & 2012 & 2019 & 2020 & & Scotland & 1 & & 385 & MW \\
\hline CAPTAIN & 2012 & 2022 & 2020 & & Scotland & 1 & & & \\
\hline Hatfield & 2013 & 2016 & 2016 & & UK & 1 & & 900 & MW \\
\hline Osaki.CoolGen & 2013 & 2017 & 2020 & 946.7 & Japan & 1 & & 166 & MW \\
\hline DonValley & 2014 & 2020 & 2020 & 8309.8 & UK & 1 & & & \\
\hline Killingholme & 2014 & 2019 & 2015 & 2424.0 & UK & 1 & & 470 & MW \\
\hline Teesside & 2014 & & 2015 & & UK & 1 & & 400 & MW \\
\hline \multicolumn{8}{|c|}{ Sources: globalccsinstitute.com; sequestration.mit.edu; for research on individual cases please contact authors } & & \\
\hline
\end{tabular}

Figure 19: Demonstration projects: 4. CCS power plants. 


\begin{tabular}{|c|c|c|c|c|c|c|c|c|c|}
\hline $\begin{array}{l}\text { CCS for industry - } \\
\text { Project cases }\end{array}$ & $\begin{array}{l}\text { Begin } \\
\text { year }\end{array}$ & On line & $\begin{array}{l}\text { End } \\
\text { year }\end{array}$ & $\begin{array}{l}\text { Budget in } \\
\text { million USD }\end{array}$ & Country & $\begin{array}{l}\text { Availability } \\
\text { Motivation } \\
\text { data } \\
\end{array}$ & $\begin{array}{l}\text { Public financial } \\
\text { contribution }\end{array}$ & $\begin{array}{l}\text { Output per } \\
\text { year }\end{array}$ & $\begin{array}{l}\text { Output } \\
\text { unit }\end{array}$ \\
\hline Sleipner & 1993 & 1996 & 2020 & & Norway & 1 & & 900000 & Tons $(\mathrm{CO} 2)$ \\
\hline Weyburn & 2000 & 2001 & 2020 & 107.2 & Canada & 1 & $7 \%$ & 1000000 & Tons(CO2 \\
\hline InSalah & 2003 & 2004 & 2011 & 3417.5 & Algeria & 1 & $0 \%$ & 1200000 & Tons(CO2 \\
\hline Ketzin & 2004 & 2008 & 2013 & 45.9 & Germany & 1 & $29 \%$ & 67271 & - Tons $(\mathrm{CO} 2$ \\
\hline ZeroGen & 2006 & 2015 & 2010 & 4.1 & Australia & 0 & $4 \%$ & 2000000 & Tons(CO2 \\
\hline Farnsworth & 2007 & 2013 & 2018 & 89.0 & USA & 1 & $67 \%$ & 200000 & Tons $(\mathrm{CO} 2$ \\
\hline Snohvit & 2007 & 2008 & 2020 & 11217.4 & Norway & 1 & $0 \%$ & 700000 & Tons(CO2 \\
\hline Otway & 2007 & 2008 & 2020 & 56.6 & Australia & 1 & $57 \%$ & 65000 & Tons(CO2 \\
\hline FortNelson & 2008 & 2014 & 2020 & 13.8 & Canada & 1 & $80 \%$ & 2200000 & Tons(CO2 \\
\hline PleasantPrairie & 2008 & 2008 & 2009 & 9.5 & USA & 1 & $84 \%$ & 15000 & Tons $(\mathrm{CO} 2$ \\
\hline Cranfield & 2009 & 2010 & 2015 & 103.2 & USA & 1 & $69 \%$ & 5371643 & Tons(CO2 \\
\hline Decatur & 2009 & 2011 & 2014 & 92.2 & USA & 1 & $79 \%$ & 333000 & Tons(CO2 \\
\hline Ordos & 2009 & 2011 & 2020 & 5533.1 & China & 1 & & 100000 & Tons (CO2 \\
\hline Gorgon & 2009 & 2016 & 2020 & 60380.7 & Australia & 1 & $1 \%$ & 4000000 & Tons(CO2 \\
\hline LEUCADIA & 2009 & 2010 & & 478.7 & USA & 1 & $60 \%$ & 4000000 & Tons(CO2 \\
\hline Alcoa & 2009 & 2010 & 2013 & 18.6 & USA & 1 & $80 \%$ & & \\
\hline Novomer & 2009 & & 2020 & 28.1 & USA & 1 & $80 \%$ & & \\
\hline Touchstone & 2009 & 2010 & & 9.2 & USA & 0 & $80 \%$ & & \\
\hline HighlandHeights & 2009 & 2010 & & 71.4 & USA & 0 & $80 \%$ & & \\
\hline Skyonic & 2009 & & 2020 & 43.5 & USA & 0 & $70 \%$ & & \\
\hline Calera & 2009 & 2010 & & 46.9 & USA & 0 & $50 \%$ & & \\
\hline Allentown & 2009 & 2012 & & 82.3 & USA & 1 & $96 \%$ & 1000000 & Tons(CO2 \\
\hline Schenectady & 2009 & & 2020 & 68.7 & USA & 0 & $50 \%$ & & \\
\hline Ramgen & 2009 & 2010 & & 87.8 & USA & 0 & $63 \%$ & & \\
\hline Praxair & 2009 & & 2020 & 61.0 & USA & 0 & $63 \%$ & & \\
\hline Pittsburgh & 2009 & & 2020 & 20.6 & USA & 0 & $80 \%$ & & \\
\hline Sandia & 2009 & & 2020 & 6.2 & USA & 0 & $78 \%$ & & \\
\hline Columbia & 2009 & & 2020 & 6.9 & USA & 0 & $80 \%$ & & \\
\hline Tuscaloosa & 2009 & & 2020 & 11.9 & USA & 0 & $46 \%$ & & \\
\hline Lawrence & 2009 & & 2020 & 6.9 & USA & 0 & $80 \%$ & & \\
\hline Laramie & 2009 & & 2020 & 5.5 & USA & 0 & $100 \%$ & & \\
\hline SwanHills & 2009 & 2014 & 2013 & 1646.7 & Canada & 0 & $19 \%$ & 1300000 & Tons(CO2 \\
\hline Barendrecht & 2009 & & 2010 & & Netherlands & 0 & & 400000 & Tons(CO2 \\
\hline Jilin & 2009 & 2009 & 2020 & 12.1 & China & 1 & & 200000 & Tons(CO2 \\
\hline Shidongkou & 2009 & 2011 & 2020 & 25.7 & China & 1 & & 120000 & Tons(CO2 \\
\hline PortArthur & 2010 & 2013 & 2020 & 467.4 & USA & 1 & $66 \%$ & 1000000 & Tons(CO2 \\
\hline AlbertaTrunk & 2010 & 2017 & 2020 & 1301.4 & Canada & 1 & $47 \%$ & 1460000 & Tons $(\mathrm{CO} 2$ \\
\hline HECA & 2010 & & 2016 & 4368.5 & USA & 1 & $10 \%$ & 2600000 & Tons(CO2 \\
\hline Eltron & 2010 & 2011 & & 79.9 & USA & 0 & $97 \%$ & & \\
\hline Triangle & 2010 & & 2020 & 188.7 & USA & 0 & $97 \%$ & & \\
\hline Orlando & 2010 & & 2020 & 70.2 & USA & 0 & $50 \%$ & & \\
\hline Windsor & 2010 & & 2020 & 13.6 & USA & 0 & $80 \%$ & & \\
\hline Menlo & 2010 & & 2020 & 20.4 & USA & 0 & $80 \%$ & & \\
\hline Arcadia & 2010 & & 2020 & 6.8 & USA & 0 & $80 \%$ & & \\
\hline Utexas & 2010 & & 2020 & 6.8 & USA & 0 & $80 \%$ & & \\
\hline FutureGen & 2010 & & 2015 & 1789.5 & USA & 1 & $61 \%$ & 1000000 & Tons(CO2 \\
\hline Citronelle & 2011 & 2011 & 2015 & 118.4 & USA & 1 & $69 \%$ & 240000 & Tons(CO2 \\
\hline ILCCS & 2011 & 2016 & 2020 & 221.0 & USA & 1 & $68 \%$ & 1000000 & Tons $(\mathrm{CO} 2$ \\
\hline BellCreek & 2011 & 2013 & 2020 & 99.9 & USA & 1 & $73 \%$ & 1000000 & Tons(CO2 \\
\hline Belchatow & 2011 & & 2013 & & Poland & 1 & & 1800000 & Tons (CO2 \\
\hline HUST & 2011 & 2017 & 2020 & & China & 1 & & 100000 & Tons $(\mathrm{CO} 2$ \\
\hline QUEST & 2012 & 2015 & 2020 & 1408.5 & Canada & 1 & $13 \%$ & 392 & Tons $(\mathrm{CO} 2$ \\
\hline Kevin & 2012 & 2016 & 2020 & 1.0 & USA & 1 & $75 \%$ & 125000 & Tons(CO2 \\
\hline IndianaGasification & 2012 & & 2013 & 2921.4 & USA & 1 & $0 \%$ & 5500000 & Tons(CO2 \\
\hline Jingbian & 2012 & 2012 & 2020 & & China & 0 & & 440000 & Tons (CO2 \\
\hline Tomakomai & 2012 & 2016 & 2020 & & Japan & 1 & & 100000 & Tons $(\mathrm{CO} 2$ \\
\hline NorthernReef & 2013 & 2013 & 2020 & 117.9 & USA & 1 & $78 \%$ & 500000 & Tons(CO2 \\
\hline Rancho & & & & & USA & 0 & $70 \%$ & & \\
\hline Littleton & . & & & & USA & 0 & $80 \%$ & & \\
\hline Champaign & 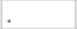 & & & & USA & 0 & $77 \%$ & & \\
\hline Greenwood & . & & & & USA & 0 & $64 \%$ & & \\
\hline Salt & . & & & & USA & 0 & $69 \%$ & & \\
\hline
\end{tabular}

Sources: globalkcsinstitute.com; sequestration.mit.edu; DOE report (2014): Carbon Capture and Sequestration; for research on individual cases please contact authors

Figure 20: Demonstration projects: 5. CCS industry. 


\begin{tabular}{|c|c|c|c|c|c|c|c|c|c|}
\hline \begin{tabular}{|l} 
Steel - \\
Project cases
\end{tabular} & $\begin{array}{l}\text { Begin } \\
\text { year }\end{array}$ & On line & $\begin{array}{l}\text { End } \\
\text { year }\end{array}$ & $\begin{array}{l}\text { Budget in } \\
\text { million USD }\end{array}$ & Country & $\begin{array}{l}\text { Availability } \\
\text { Motivation } \\
\text { data } \\
\end{array}$ & $\begin{array}{l}\begin{array}{l}\text { Public financial } \\
\text { contribution }\end{array} \\
\end{array}$ & $\begin{array}{l}\text { Output per } \\
\text { year }\end{array}$ & $\begin{array}{l}\text { Output } \\
\text { unit }\end{array}$ \\
\hline COREX.GER & 1981 & 1989 & & & Germany & 1 & $100 \%$ & & \\
\hline NKK.KEIHAN & 1988 & 1993 & 1996 & & Japan & 1 & & 100000 & Tons(CO2) \\
\hline AISI.PENN & 1989 & 1994 & & 102.2 & USA & 1 & $77 \%$ & & \\
\hline JUPITER.USINOR & 1989 & & 2020 & & France & 1 & & & \\
\hline FINEX.VAI & 1992 & 1993 & & & Austria & 1 & & 50000 & Tons(CO2) \\
\hline COREX.USA & 1995 & 1999 & & 1201.3 & USA & 0 & $18 \%$ & & \\
\hline ULCOS & 2003 & & 2015 & 107.1 & EU, Norway & 1 & $40 \%$ & & \\
\hline Mikawa & 2005 & 2009 & 2020 & 4.6 & Japan & 0 & & 360000 & Tons (CO2) \\
\hline Florange & 2007 & & 2009 & & & 0 & & & \\
\hline ESI & 2007 & 2016 & 2020 & 16917.5 & UAE & 0 & $83 \%$ & 800000 & Tons $\left(\mathrm{CO}_{2}\right)$ \\
\hline Caofeidian & 2007 & 2009 & & & China & 0 & & 1000000 & Tons(CO2) \\
\hline AISI.UTAH & 2010 & 2011 & & 5.3 & USA & 1 & & & \\
\hline AbuDhabi & 2013 & 2016 & 2020 & 125.8 & UAE & 1 & $100 \%$ & 800000 & Tons $\left(\mathrm{CO}_{2}\right)$ \\
\hline
\end{tabular}

Figure 21: Demonstration projects: 6. Steel.

\begin{tabular}{|c|c|c|c|c|c|c|c|c|c|}
\hline $\begin{array}{l}\text { Cement - } \\
\text { Project cases }\end{array}$ & $\begin{array}{l}\text { Begin } \\
\text { year }\end{array}$ & On line & $\begin{array}{l}\text { End } \\
\text { year }\end{array}$ & $\begin{array}{l}\text { Budget in } \\
\text { million USD }\end{array}$ & Country & $\begin{array}{l}\text { Availability } \\
\text { Motivation } \\
\text { data }\end{array}$ & $\begin{array}{l}\text { Public financial } \\
\text { contribution }\end{array}$ & $\begin{array}{l}\begin{array}{l}\text { Output per } \\
\text { year }\end{array} \\
\end{array}$ & $\begin{array}{l}\text { Output } \\
\text { unit }\end{array}$ \\
\hline Richmond & 2009 & 2016 & & & Canada & 1 & 1 & 36.5 & Tons $(\mathrm{CO} 2)$ \\
\hline Cemex & 2009 & 2010 & & 1561.1 & USA & 1 & $80 \%$ & 1000000 & Tons (CO2) \\
\hline Dania & 2009 & 2009 & 2020 & & Denmark & 1 & 1 & & \\
\hline Sunrise & 2009 & & 2020 & & USA & 0 & & & \\
\hline ECRA & 2010 & 2017 & 2020 & 55.5 & EU & 1 & 1 & 540000 & Tons $(\mathrm{CO} 2)$ \\
\hline HUALIEN & 2012 & 2013 & & & Taiwan & 1 & 1 & 36000 & Tons (CO2) \\
\hline BREVIK & 2013 & 2013 & 2017 & 16.3 & Norway & 1 & $75 \%$ & 10000 & Tons(CO2) \\
\hline Skyonic & 2013 & 2014 & 2020 & 128.3 & USA & 1 & $10 \%$ & 83000 & Tons $(\mathrm{CO} 2)$ \\
\hline St.Marys & 2013 & 2014 & & 128.3 & Canada & 1 & 1 & & \\
\hline
\end{tabular}

Figure 22: Demonstration projects: 7. Cement.

\begin{tabular}{|c|c|c|c|c|c|c|c|c|c|}
\hline $\begin{array}{l}\text { Synthetic Fuels - } \\
\text { Project cases }\end{array}$ & $\begin{array}{l}\text { Begin } \\
\text { year }\end{array}$ & On line & $\begin{array}{l}\text { End } \\
\text { year }\end{array}$ & $\begin{array}{l}\text { Budget in } \\
\text { million USD }\end{array}$ & Country & $\begin{array}{l}\text { Availability } \\
\text { Motivation } \\
\text { data }\end{array}$ & $\begin{array}{l}\text { Public financial } \\
\text { contribution }\end{array}$ & $\begin{array}{l}\text { Output per } \\
\text { year }\end{array}$ & $\begin{array}{l}\text { Output } \\
\text { unit }\end{array}$ \\
\hline EXXON & 1964 & & 1984 & 6858.8 & USA & 1 & $11 \%$ & 17155000 & Barrels \\
\hline CREEK & 1978 & 1983 & 1991 & 957.0 & USA & 1 & $0 \%$ & 1898000 & Barrels \\
\hline SFC & 1981 & & 1986 & 11845.1 & USA & 1 & $67 \%$ & & \\
\hline GreatPlains & 1981 & 1984 & 2020 & 4557.6 & USA & 1 & $76 \%$ & 5840000 & Tons(coal) \\
\hline CWGP & 1983 & 1984 & 1989 & 245.5 & USA & 1 & & 310250 & Tons(coal) \\
\hline Dow & 1984 & 1987 & 1995 & 1225.0 & USA & 1 & & 576700 & Tons(coal) \\
\hline HILL & 1985 & 1987 & 1990 & 114.9 & USA & 1 & 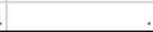 & 511000 & Barrels \\
\hline
\end{tabular}

Figure 23: Demonstration projects: 8. Synthetic fuels. 


\begin{tabular}{|c|c|c|c|c|c|c|c|c|c|}
\hline $\begin{array}{l}\text { Cellulosic Biofuels - } \\
\text { Project cases }\end{array}$ & $\begin{array}{l}\text { Begin } \\
\text { year }\end{array}$ & On line & $\begin{array}{l}\text { End } \\
\text { year }\end{array}$ & $\begin{array}{l}\text { Budget in } \\
\text { million USD }\end{array}$ & Country & $\begin{array}{l}\text { Availability } \\
\text { Motivation } \\
\text { data }\end{array}$ & $\begin{array}{l}\text { Public financial } \\
\text { contribution }\end{array}$ & $\begin{array}{l}\text { Output per } \\
\text { year }\end{array}$ & $\begin{array}{l}\text { Output } \\
\text { unit }\end{array}$ \\
\hline NREL TCUF & 1985 & & 2020 & 57.4 & USA & 1 & & 1.4 & mgallon \\
\hline NREL IBRF & 1994 & & 2020 & 74.3 & USA & 1 & $100 \%$ & 0.01 & mgallon \\
\hline Enerkem Sherbrooke & 2002 & 2003 & 2020 & & Canada & 1 & & & \\
\hline Mascoma - pilot/demo & 2002 & 2003 & 2020 & & USA & 0 & & 0.125 & mgallon \\
\hline logen & 2003 & 2004 & 2020 & & Canada & 1 & & 0.23 & mgallon \\
\hline SEKAB & 2003 & 2004 & 2020 & 0.3 & Sweden & 1 & & 0.01 & mgallon \\
\hline GTI & 2004 & & 2020 & 3.7 & USA & 1 & $81 \%$ & 0.35 & mgallon \\
\hline Oxford Catalysts & 2005 & & 2020 & & Austria & 0 & & 0.01 & mgallon \\
\hline Abengoa pilot & 2006 & 2007 & 2020 & 41.1 & USA & 0 & & 10 & mgallon \\
\hline Aemetis & 2008 & 2009 & 2020 & 1.7 & USA & 1 & & 0.16 & mgallon \\
\hline AE biofuels pilot & 2008 & & 2020 & & USA & 0 & & 0.15 & mgallon \\
\hline Amyris pilot & 2008 & 2010 & 2013 & 39.3 & USA & 1 & $70 \%$ & 0.01 & mgallon \\
\hline BornBiofuel 1 & 2008 & 2009 & 2010 & 12.4 & Denmark & 1 & $48 \%$ & 0.0003 & mgallon \\
\hline Chempolis & 2008 & 2011 & 2020 & 32.4 & Finland & 1 & & 3.7 & mgallon \\
\hline Enerkem Westbury & 2008 & 2009 & 2020 & & Canada & 1 & & 1.3 & mgallon \\
\hline ENN & 2008 & 2009 & & & & 0 & & 0.01 & mgallon \\
\hline Blue Sugars & 2008 & 2009 & 2010 & & USA & 1 & $0 \%$ & 1.3 & mgallon \\
\hline Lanza Tech & 2008 & 2011 & 2020 & & China & 0 & & 0.1 & mgallon \\
\hline Lignol & 2008 & 2009 & 2020 & 20.7 & Canada & 1 & & 0.02 & mgallon \\
\hline NationalTechnologicalUni. & 2008 & & 2020 & & Argentina & 0 & & 0.01 & mgallon \\
\hline BornBiofuel opt & 2009 & 2009 & 2012 & 2.4 & Denmark & 1 & $58 \%$ & 0.004 & mgallon \\
\hline ADM & 2009 & 2012 & 2020 & 39.5 & USA & 1 & $69 \%$ & 1 & mgallon \\
\hline Amyris demo & 2009 & 2013 & 2020 & & Brazil & 0 & & 27 & mgallon \\
\hline BP Biofuels Jennings & 2009 & 2012 & 2020 & 86.7 & USA & 0 & & 1.4 & mgallon \\
\hline Butalco & 2009 & 2010 & & & Germany & 0 & & 0.01 & mgallon \\
\hline Butamax & 2009 & 2010 & & & UK & 0 & & 160.5 & mgallon \\
\hline Beta Renewables pilot & 2009 & 2012 & 2020 & & Italy & 0 & $0 \%$ & 12 & mgallon \\
\hline Choren & 2009 & 2010 & & & Germany & 0 & & 4.1 & mgallon \\
\hline Dynamic Fuels & 2009 & 2010 & & 151.5 & USA & 1 & & 75 & mgallon \\
\hline Dynamotive & 2009 & 2010 & & & Canada & 0 & & 1.01 & mgallon \\
\hline Enerkem Pontotok & 2009 & 2020 & 2020 & 153.7 & USA & 1 & $36 \%$ & 10 & mgallon \\
\hline Inbicon demo & 2009 & & 2020 & 76.3 & Denmark & 0 & $80 \%$ & 1.4 & mgallon \\
\hline BioCentury & 2009 & & 2020 & 19.8 & USA & 1 & $14 \%$ & 62.5 & mgallon \\
\hline LS9 / Florida & 2009 & 2010 & & 0.1 & USA & 0 & & 10 & mgallon \\
\hline Queensland Algal project & 2009 & 2010 & & 9.0 & Australia & 0 & & 0.01 & mgallon \\
\hline Range Fuels & 2009 & 2010 & & & USA & 0 & & 20 & mgallon \\
\hline Gridley project & 2009 & 2012 & & & USA & 0 & & 0.35 & mgallon \\
\hline Terrabon & 2009 & 2010 & & & USA & 0 & & 0.1 & mgallon \\
\hline Virent & 2009 & 2010 & 2020 & & USA & 0 & & 0.01 & mgallon \\
\hline Weyland / Statoil Hydro & 2009 & 2010 & 2020 & 9.9 & Norway & 0 & & 0.05 & mgallon \\
\hline Aquatic Energy & 2010 & 2011 & & & USA & 0 & & 0.03 & mgallon \\
\hline Avantium & 2010 & 2011 & & & Netherlands & 1 & & 0.01 & mgallon \\
\hline BARD & 2010 & 2011 & & & USA & 1 & & 10 & mgallon \\
\hline BioGasol & 2010 & 2011 & & & Denmark & 1 & & 0.08 & mgallon \\
\hline BioTfuel 2 & 2010 & 2012 & & 17.2 & France & 0 & & 0.02 & mgallon \\
\hline BioProcess Algae & 2010 & 2011 & & & USA & 0 & & 0.01 & mgallon \\
\hline Bluefire Renewables & 2010 & 2011 & & & USA & 0 & & 3.91 & mgallon \\
\hline Clearfuels & 2010 & 2011 & & 39.6 & USA & 0 & $63 \%$ & 0.07 & mgallon \\
\hline COFCO/Sinopec & 2010 & 2011 & & & China & 0 & & 3 & mgallon \\
\hline Futurol & 2010 & 2011 & 2019 & 109.7 & France & 1 & $39 \%$ & 0.9 & mgallon \\
\hline Greenfield Ethanol & 2010 & 2011 & & & Canada & 1 & & 0.01 & mgallon \\
\hline HCL Clean Tech & 2010 & 2011 & & & USA & 0 & & 0.01 & mgallon \\
\hline Helios & 2010 & 2011 & & & USA & 1 & & 0.03 & mgallon \\
\hline Kumho Petrochemical & 2010 & 2011 & & 19.1 & Korea & 0 & & 0.386 & mgallon \\
\hline Maverick Biofuels & 2010 & 2011 & & & USA & 0 & & 0.01 & mgallon \\
\hline NEDO & 2010 & 2011 & 2020 & & Japan & 1 & & 0.02 & mgallon \\
\hline Phycal & 2010 & 2011 & & & USA & 0 & & 0.01 & mgallon \\
\hline Pond Biofuels & 2010 & 2011 & & 4.3 & Canada & 0 & & 0.01 & mgallon \\
\hline Primus Green Energy & 2010 & 2011 & & & USA & 0 & & 0.01 & mgallon \\
\hline St1 Biofuels Oy & 2010 & 2011 & & & Finland & 0 & & 0.01 & mgallon \\
\hline Sunliquid & 2010 & 2012 & 2020 & 40.2 & Germany & 1 & & 0.6 & mgallon \\
\hline
\end{tabular}

Figure 24: Demonstration projects: 9. Cellulosic biofuels, part 1. 


\begin{tabular}{|c|c|c|c|c|c|c|c|c|c|}
\hline $\begin{array}{l}\text { Cellulosic Biofuels - } \\
\text { Project cases }\end{array}$ & $\begin{array}{l}\text { Begin } \\
\text { year }\end{array}$ & On line & $\begin{array}{l}\text { End } \\
\text { year }\end{array}$ & $\begin{array}{l}\text { Budget in } \\
\text { million USD }\end{array}$ & Country & $\begin{array}{l}\text { Availability } \\
\text { Motivation } \\
\text { data } \\
\end{array}$ & $\begin{array}{l}\text { Public financial } \\
\text { contribution }\end{array}$ & $\begin{array}{l}\text { Output per } \\
\text { year }\end{array}$ & $\begin{array}{l}\text { Output } \\
\text { unit }\end{array}$ \\
\hline UOP-Aquaflow Bionomic & 2010 & 2011 & & & USA & 1 & & 0.01 & mgallon \\
\hline Velocys & 2010 & 2011 & & & Brazil & 0 & & 0.01 & mgallon \\
\hline Woodland Biofuels & 2010 & 2011 & & & Canada & 0 & & 0.02 & mgallon \\
\hline AltAir & 2011 & 2012 & & & USA & 0 & & 100 & mgallon \\
\hline American Process & 2011 & 2012 & & 29.8 & USA & 0 & $64 \%$ & 0.89 & mgallon \\
\hline Aurora Algae-demo & 2011 & 2011 & 2013 & & Australia & 0 & & 0.02 & mgallon \\
\hline Borregaard Bali demo & 2011 & 2012 & 2020 & 23.6 & Norway & 0 & $45 \%$ & 0.11 & mgallon \\
\hline UF demo & 2011 & 2012 & & 21.3 & USA & 1 & $100 \%$ & 0.01 & mgallon \\
\hline BioDME & 2011 & & 2012 & 42.1 & Sweden & 1 & & 0.58 & mgallon \\
\hline Coskata & 2011 & 2012 & & & USA & 0 & & 55.05 & mgallon \\
\hline Diamond Green & 2011 & 2012 & & & USA & 0 & & 137 & mgallon \\
\hline Dupont-BAL & 2011 & 2012 & & & & 0 & & 0.01 & mgallon \\
\hline Fulcrum & 2011 & 2012 & & & USA & 0 & & 10.51 & mgallon \\
\hline Green Star Products & 2011 & 2012 & & & USA & 0 & & 2 & mgallon \\
\hline Haldor & 2011 & 2012 & & 37.2 & USA & 0 & $72 \%$ & 0.8 & mgallon \\
\hline KiOR-demonstration & 2011 & & 2014 & 1062.6 & USA & 0 & $50 \%$ & 0.23 & mgallon \\
\hline KiOR - 1st commercial & 2011 & 2012 & & & USA & 0 & & 62.5 & mgallon \\
\hline MBD Energy & 2011 & 2013 & & 11.7 & Australia & 0 & & 3 & mgallon \\
\hline Greasoline & 2011 & & 2020 & 4.4 & Germany & 1 & & 0.0006 & mgallon \\
\hline ZeaChem demo & 2011 & 2012 & 2020 & 78.1 & USA & 0 & $34 \%$ & 0.25 & mgallon \\
\hline Abengoa Arance & 2012 & 2013 & 2020 & 14.3 & France & 1 & $82 \%$ & 13.38 & mgallon \\
\hline BornBiofuel 2 & 2012 & 2013 & & 36.9 & Denmark & 1 & $38 \%$ & 1.34 & mgallon \\
\hline BioTfuel 1 & 2012 & 2017 & & 147.5 & France & 0 & & & \\
\hline Chemrec - commercial & 2012 & 2013 & & 462.0 & Sweden & 0 & $17 \%$ & 46.82 & mgallon \\
\hline Idemitsu Kosan & 2012 & 2013 & & & Japan & 1 & & 0.01 & mgallon \\
\hline KiOR - 2nd commercial & 2012 & 2013 & & & USA & 0 & & 62.5 & mgallon \\
\hline Abengoa Hugoton & 2013 & & 2020 & & USA & 1 & & 15 & mgallon \\
\hline British Airways/Solena & 2013 & 2014 & & & UK & 0 & & 19 & mgallon \\
\hline DDCE & 2013 & 2014 & & 241.3 & USA & 0 & $4 \%$ & 25 & mgallon \\
\hline Fiberight & 2013 & & 2020 & 24.6 & USA & 1 & & 6 & mgallon \\
\hline INEOS Vero & 2013 & & 2020 & 135.5 & USA & 0 & $38 \%$ & 8 & mgallon \\
\hline KiOR - 3rd commercial & 2013 & 2014 & & 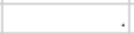 & USA & 0 & & 62.5 & mgallon \\
\hline KiOR - 4th commercial & 2013 & 2014 & & & USA & 0 & & 62.5 & mgallon \\
\hline Trenton Fuel Works & 2013 & 2014 & & 68.8 & USA & 0 & & 3.87 & mgallon \\
\hline Tubitak & 2013 & & 2020 & 11.6 & Turkey & 0 & & 0.01 & mgallon \\
\hline ZeaChem comm & 2013 & 2014 & & & USA & 1 & & 25 & mgallon \\
\hline Algae.Tec & . & & & & Australia & 0 & & 0.01 & mgallon \\
\hline Algenol-demon & . & & & & Mexico & 0 & & 0.1 & mgallon \\
\hline Algenol-firstcommercial & . & & & & Mexico & 0 & & 750 & mgallon \\
\hline Algenol (3) & . & & & & USA & 0 & $42 \%$ & 0.1 & mgallon \\
\hline Aurora Algae - pilot & . & & & & USA & 0 & & 0.5 & mgallon \\
\hline Bluefire 1 & . & & & & USA & 0 & $27 \%$ & 19 & mgallon \\
\hline Citrus Energy & . & & & & USA & 0 & & 4 & mgallon \\
\hline Clemson & . & & & & USA & 0 & & 10 & mgallon \\
\hline Cobalt -pilot & . & & & & USA & 0 & & 0.01 & mgallon \\
\hline Dupont Danisco & . & & & & USA & 0 & & 0.25 & mgallon \\
\hline Gevo & . & & & & USA & 1 & & 300 & mgallon \\
\hline ICM & . & & & & USA & 0 & $81 \%$ & 1.5 & mgallon \\
\hline Gulf Coast Energy & . & & & & USA & 0 & & 25 & mgallon \\
\hline Gulf Coast Energy pilot & . & & & & USA & 0 & & 0.4 & mgallon \\
\hline Logos & . & & & & USA & 0 & $80 \%$ & & \\
\hline Mascoma commercial & . & & & & USA & 0 & & 40 & mgallon \\
\hline Muradel & . & & & & Australia & 0 & & 0.01 & mgallon \\
\hline PetroAlgae & . & & & & USA & 0 & & 0.12 & mgallon \\
\hline Toledo REII & . & & & & USA & 0 & $80 \%$ & & \\
\hline Rentech & . & & & & USA & 0 & & 0.15 & mgallon \\
\hline Sapphire Energy & . & & & & USA & 0 & $37 \%$ & 1.02 & mgallon \\
\hline Scottish Bioenergy & . & & & & Scotland & 0 & & 0.01 & mgallon \\
\hline Seambiotic & . & & & & Israel & 0 & & 0.01 & mgallon \\
\hline Solazyme & . & & & & USA & 0 & $86 \%$ & 0.01 & mgallon \\
\hline SunOpta & . & & & & USA & 0 & & 10 & mgallon \\
\hline ThermoChem Recovery & . & & & & USA & 0 & & 0.01 & mgallon \\
\hline UOP LLC & . & & & & USA & 0 & $79 \%$ & & \\
\hline Verenium & . & & & & USA & 0 & & 1.4 & mgallon \\
\hline Verenium BP comm & . & & & & USA & 0 & & 36 & mgallon \\
\hline
\end{tabular}

Figure 25: Demonstration projects: 9. Cellulosic biofuels, part 2. 